\title{
Ofac
}

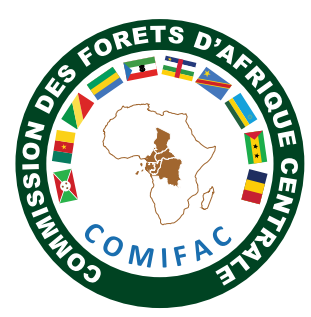

Mapping international funding flows to support forest and environmental sectors in Central Africa

Ibrahim M. Favada

Richard Eba'a Atyi

Liboum Mbonayem

Philippe Guizol 



\section{Mapping international funding flows to support forest and environmental sectors in Central Africa}

Ibrahim M. Favada

Richard Eba'a Atyi

Liboum Mbonayem

Philippe Guizol 
(c) 2019 Center for International Forestry Research

(c) (1) Content in this publication is licensed under a Creative Commons Attribution 4.0 International (CC BY 4.0), http://creativecommons.org/licenses/by/4.0/

DOI: 10.17528/cifor/007416

Favada IM, Atyi RE, Mbonayem L and Guizol P. 2019. Mapping international funding flows to support forest and environmental sectors in Central Africa. Bogor, Indonesia: CIFOR.

Photo by Ollivier Girard/CIFOR

On the way back to the Village

\author{
CIFOR \\ Jl. CIFOR, Situ Gede \\ Bogor Barat 16115 \\ Indonesia \\ $\mathrm{T}+62(251) 8622-622$ \\ $F+62$ (251) 8622-100 \\ E cifor@cgiar.org
}

\title{
cifor.org
}

We would like to thank all donors who supported this work through their contributions to the CGIAR Trust Fund: https://www.cgiar.org/funders/

Any views expressed in this publication are those of the authors. They do not necessarily represent the views of CIFOR, the editors, the authors' institutions, the financial sponsors or the reviewers. 


\section{Content}

List of abbreviations and acronyms v v

Acknowledgments $\quad$ vi

Executive summary vii

1 Introduction 1

1.1 Background 1

1.2 Objectives and scope of study 1

1.3 Organization of the report 1

2 Methodology 2

2.1 Study approach 2

2.2 Data and its sources 2

2.3 Methodological limitations 2

3 Funding flows to support forest and environmental sectors in Central Africa $\quad 4$

3.1 Analysis of funding flows 4

3.2 Imbalances and gaps in flows 8

3.3 Comparative study of funding flows in CA and other tropical zones 12

3.4 Needs and opportunities for financing forest and environment in Central Africa 20

4 Conclusions 24

4.1 Strengthening external financing of forest and environmental sectors in
Central Africa

Appendices $\quad 26$

1 Terms of Reference 26

2 Breakdown of FEODA (USD million) 29

3 Share by donor of total FEODA (USD million) 30

4 Recipients of total FEODA (USD million) 31

5 Recipients of bilateral FEODA (USD million) 32

6 Recipients of multilateral FEODA (USD million) 33

7 Total FEODA by area and by tropical zone (USD million) 34

8 Bilateral FEODA by area and by tropical zone (USD million) 36

9 Multilateral FEODA by area and by tropical zone (USD million) 38 


\section{List of figures and tables}

\section{Figures}

1 Study approach 2

2 Trends in total forest and environmental flows 5

3 Trends in bilateral and multilateral FEODA, 2008-2017 5

4 Share of total FEODA by donor 6

5 Share of bilateral FEODA by donor, 2008-2017 6

6 Share of multilateral FEODA by donor, 2008-2017 7

7 Recipients of FEODA in CA, 2008-2017 7

8 Recipients of bilateral and multilateral FEODA in CA, 2008-2017 8

9 Areas covered by FEODA 9

10 Areas covered by bilateral FEODA, 2008-2017 9

11 Areas covered by multilateral FEODA, 2008-2017 10

12 Trends in FEODA, 2008-2017 10

\section{Tables}

1 Areas covered by flows 3

2 ITTO focus areas grouped under OECD focus areas 3

3 Forest and environmental flows to CA, million USD 4

4 Bilateral and multilateral donor presence and absence in CA 11

5 Bilateral frequency of funding and no funding by year 11

6 Multilateral frequency of funding by year $\quad 12$

7 Forest and environmental flows to tropical zones, 2008-2017 13

8 Bilateral funding areas by topical zone 14

9 Multilateral Funding Areas by Topical Zone 16

10 Total FEODA funding areas by topical zone 17

11 Bilateral Donors by Tropical Zone, 2008-17 19

12 Multilateral donors by tropical zone, 2008-2017 20

13 Selected forestry and environmental statistics of Congo Basin countries 21

14 Funding initiatives to support forest and environment 22 


\section{List of abbreviations and acronyms}

\begin{tabular}{ll} 
AfDB & African Development Bank \\
CA & Central Africa \\
CAFI & Central African Forest Initiative \\
CAR & Central African Republic \\
CBFF & Congo Basin Forest Fund \\
CBFP & Congo Basin Forest Partnership \\
CIF & Climate Investment Fund \\
COMIFAC & Central African Forest Commission \\
DAC & Development Assistance Committee \\
DRC & Democratic Republic of Congo \\
EODA & Environmental official development assistance \\
EU & European Union \\
FAO & Food and Agriculture Organization \\
FCPF & Forest Carbon Partnership Facility \\
FEODA & Forestry and environmental official development assistance \\
GCCA & Global Climate Change Alliance \\
GCF & Green Climate Fund \\
GEF & Global Environmental Facility \\
GGGI & Global Green Growth Institute \\
ITTO & International Tropical Timber Organization \\
LDCF & Least Developing Country Fund \\
NGO & Non-governmental organization \\
NDF & Nordic Development Fund \\
ODA & Official Development Assistance \\
OECD & Organization of Economic Cooperation and Development \\
OFAC & Observatory for the Forests of Central Africa \\
REDDES & Reducing deforestation and forest degradation and enhancing environmental services \\
RIOFAC & Renforcement et Institutionnalisation de l'Observatoire des Forêts d'Afrique Centrale \\
SCCF & Special Climate Change Fund \\
UNDP & United Nation Development Program \\
UN-REDD & United Nations Programme on Reducing Emissions from Deforestation and \\
& Forest Degradation \\
& \\
\hline &
\end{tabular}




\section{Acknowledgments}

This report is published under the tutelage of the Central Africa Forest Observatory (OFAC), which is a technical branch of the Central African Forest Comission (COMIFAC). We would like to recognize the important role of the Executive Secretary of COMIFAC, Mr. Raymond NDOMBAGOYE and his staff in promoting the publication of this report especially towards Central Africa's policy makers. The report is an output of the RIOFAC project that supports OFAC, and which receives funding from the European Commission through the Delegation of the European Union in Cameroon. We are very thankful to all the EU staff who have been involved in setting the enabling conditions for the project to function adequately, particularly Philippe Mayaux, Emilie Wattelier, Nick Goetschalckx and Sylvannie Jardinet.

The OFAC operations are ran daily by a few staff who contribute to the achievement of all outputs they include; Florence Palla, Quentin Jungers, Vincent Medjibe, Donald Njossi and Loic Kenmou. We would like to express our gratitude to them. 


\section{Executive summary}

Financing of the forestry and environmental sectors in Central Africa (CA) was selected by representatives of Central African Forest Commission (COMIFAC) member countries as the focus for a policy analysis paper. The Strengthening and Institutionalization of the Central African Forest Observatory (RIOFAC) project, funded by the European Union, also prioritises this subject. RIOFAC is designed to support the Central Africa Forest Observatory (OFAC) in its efforts to reinforce national capacity to collect, analyse and disseminate relevant information for decision making on forest and forest-reacted sectors.

Forests and environment financing is a central issue in global discussions on to how to combat climate change. Numerous funding initiatives have been established to support forest and environmental sectors. For example, 34 projects were internationally funded in the period 2000-2007 (OECD, 2019); 16 of these projects were funded by bilateral sources and 18 by multilateral sources.

The objective of this study was to map out international funding flows, which will support the forest and environmental sectors in CA. This will serve as background for the policy analysis paper. Specific objectives include: (a) analysis of financing flows directed to CA over the last decade in support of nature conservation, sustainable forest management and climate change; (b) presentation of themes or areas covered by the current financing flows and identification of possible imbalances and gaps; (c) provision of a comparative analysis between financing flows to CA and those directed to Tropical America (Amazon Basin) and Tropical Asia (Southeast Asia); and (d) identification of needs and opportunities for financing the forest and environmental sectors of CA.
The study used desk research, flow analysis, and identification of needs and opportunities for official development assistance (ODA) to CA. The desk research identified data sources, which include Organization of Economic Cooperation and Development (OECD) statistics and annual reports of the International Tropical Timber Organization (ITTO). The flow analysis focused on donors, recipients, areas covered by the flows, imbalances and gaps in flows. It compared flows to CA with those of other tropical zones (Amazon Basin and Southeast Asia). The OECD commitment data were used instead of disbursement data, because the latter may not be complete and updated for all donors.

\section{Analysis of funding flows}

The bilateral and multilateral flows to forests and the environment totaled approximately USD 2 billion over 2008-2017. EODA accounted for more than three-quarters of the total FEODA. Over the study period, the evolution of bilateral and multilateral flows was unsteady, fluctuating widely. Since 2015 , both flows have steadily decreased.

The top five total FEODA donors, in descending order, were Germany, EU, GEF, United States and World Bank. The top five bilateral FEODA donors, in descending order, were Germany, United States, France, Japan and Sweden. Finland and Denmark were completely absent in CA during the study period. The top five multilateral FEODA donors, in descending order, were EU, GEF, World Bank, CIF and AfDB. GCF and Adaptation Fund were completely absent in CA during the study period. Germany is top 1 donor of total FEODA (bilateral FEODA and multilateral FEODA). 
The top five recipients of the total FEODA, in descending order, were DRC, Chad, Cameroon, Rwanda and Gabon. Equatorial Guinea and Sao Tome and Principe accounted for less than 1\% of the total FEODA individually. The top five recipients of bilateral FEODA, in descending order, were DRC, Chad, Cameroon, Rwanda and Gabon. The top five recipients of multilateral FEODA, in descending order, were DRC, Chad, Cameroon, Rwanda and Congo. Equatorial Guinea and Sao Tome and Principe accounted for the lowest share $(0.1 \%)$ of the multilateral and bilateral FEODA respectively.

The top five areas covered by total FEODA, in descending order, were biodiversity, environmental policy and administrative management,

forestry policy and administrative management, environmental research, and biosphere protection. The top five areas covered by the bilateral FEODA, in descending order, included biodiversity, environmental policy and administrative management, environmental research, forest policy and administrative management, and forest development. The top five areas covered by multilateral flows, in descending order, were environmental policy and administrative management, biodiversity, biosphere protection, forest policy and administrative management, and forest development.

The top five areas covered by total FEODA accounted for $89 \%$ of the total FEODA value. This constitutes a thematic imbalance of the total FEODA to CA.

Bilateral donor presence was high in Rwanda, Cameroon, DRC and Congo, and lowest in Equatorial Guinea. Bilateral donor absence was high in Equatorial Guinea, Sao Tome and Principe, Chad and Gabon. Cameroon and Rwanda recorded the lowest number of donor absences. Fourteen donors were absent in Equatorial Guinea and 12 absent in Sao Tome and Principe. Seventeen bilateral donors contributed 470 bilateral ODA flows to CA during 2008-2017. The DRC received the largest share, followed by Rwanda and Cameroon. Equatorial Guinea and Sao Tome and Principe received less than $5 \%$ of the total number of bilateral ODAs to CA. On average, the DRC received 9 bilateral ODAs per year, followed by Cameroon and Rwanda (8 each), Congo (5), Chad and Gabon (4 each), Burundi and CAR (3 each), Equatorial Guinea (2), and Sao
Tome and Principe (1). Burundi did not receive bilateral ODA in 2017 and Sao Tome and Principe did not receive ODA in 2010, 2011 and 2015.

Multilateral donor presence was high in Rwanda, Congo, DRC and Cameroon. Equatorial Guinea recorded the lowest number of multilateral donor. Equatorial Guinea recorded the highest number of multilateral donor absences, followed by Burundi and Sao Tome and Principe. Ten multilateral donors were absent in Equatorial Guinea. Twelve multilateral donors contributed 189 multilateral ODA flows to CA. Cameroon received the highest number of multilateral ODA flows, followed by DRC, Congo and Chad. On average, Cameroon, Congo and DRC received about three multilateral ODAs, followed by Burundi, CAR, Chad, Gabon and Rwanda received 2 each, and Equatorial Guinea and Sao Tome and Principe received 1 each. Burundi did not receive multilateral ODA in 2010. CAR did not receive multilateral ODA in 2015. Equatorial Guinea did not receive multilateral ODA from 2014 to 2017. Gabon did not receive multilateral ODA in 2008. Sao Tome and Principe did not receive multilateral ODA in 2009, 2010 and from 2014 to 2017.

CA recorded the lowest share of total FEODA directed to the three tropical zones, the Amazon Basin, CA and Southeast Asia. Southeast Asia received the most.

In CA, the top five areas covered by bilateral flows, in order of importance, were biodiversity, environmental policy and administrative management, environmental research, forestry policy and administrative management, and forest development. In the Amazon Basin, the top five areas covered, in order of importance, were environmental policy and administrative management, biodiversity, biosphere protection, forestry policy and administrative management, and forestry development. In Southeast Asia, the top five areas covered, in order of importance, were environmental policy and administrative management, flood prevention or control, biodiversity, forestry policy and administrative management, and biosphere protection.

Comparing the top five areas covered by bilateral flows in CA, Amazon Basin and Southeast Asia, the common areas covered by bilateral flows are biodiversity, environmental policy and administrative management, and forestry policy 
and administrative management. Biodiversity ranked first for CA, second for the Amazon Basin and third for Southeast Asia. Environmental policy and administrative management ranked second for CA, first for Amazon Basin and Southeast Asia. Forestry policy and administrative management ranked fourth for CA, Amazon Basin and Southeast Asia.

In CA, the top five areas covered by multilateral flows, in order of importance, were environmental policy and administrative management, biodiversity, biosphere protection, forestry policy and administrative management, and forestry development. In the Amazon Basin, the top five areas covered by multilateral flows, in order of importance, were biodiversity, environmental policy and administrative management, forestry policy and administrative management, flood prevention or control and forestry development. In Southeast Asia, the top five areas covered by multilateral flows, in order of importance, were environmental policy and administrative management, flood prevention or control, biodiversity, forestry policy and administrative management, and forestry development.

Comparing the top five areas covered by flows in CA, the Amazon Basin and Southeast Asia, the common areas covered by multilateral flows were environmental policy and administrative management, biodiversity, forestry policy and administrative management, and forestry development. Environmental policy and administrative management ranked first for $\mathrm{CA}$ and Southeast Asia and second place for Amazon Basin. Biodiversity ranked first for Amazon Basin, second place for CA and third place for Southeast Asia. Forestry policy and administrative management ranked third for Amazon Basin and fourth for CA and Southeast Asia. Forestry development ranked fifth for the three tropical zones.

In CA, the top five areas covered by total FEODA, in order of importance, were biodiversity, environmental policy and administrative management, forestry policy and administrative management, environmental research and biosphere protection. In the Amazon Basin, the top five areas covered, in order of importance, were environmental policy and administrative management, biodiversity, biosphere protection, forestry policy and administrative management, and flood prevention or control. In Southeast Asia, the top five areas covered, in order of importance, were environmental policy and administrative management, flood prevention or control, biodiversity, forestry policy and administrative management, and biosphere protection. Comparing the top five areas covered by FEODA flows in CA, the Amazon Basin and Southeast Asia, the common areas covered by FEODA flows were environmental policy and administrative management, biodiversity, forestry policy and administrative management, and biosphere protection. Environmental policy and administrative management ranked first for Amazon Basin and Southeast Asia, and second for CA. Biodiversity ranked first for CA, second for Amazon Basin and third for Southeast Asia. Forestry policy and administrative management ranked third for CA and Amazon Basin, and fourth for Southeast Asia. Biosphere protection ranked fourth for Amazon Basin and fifth for CA and Southeast Asia.

In CA, the top five bilateral donors, in order of importance, were Germany, the United States, France, Japan and Sweden. In the Amazon Basin, the five top bilateral donors, in order of importance, were Norway, Germany, France, the United States and Japan. In Southeast Asia, the top five bilateral donors, in order of importance, were Japan, France, the United States, Germany and Norway.

In CA the top five multilateral donors, in order of importance, were the EU, GEF, EB, CIF and AfDB. In the Amazon Basin, the top five multilateral donors, in order of importance, were GEF, the EU, CIF, GCF and World Bank. 



\section{Introduction}

\subsection{Background}

During a regional workshop held in Brazzaville in February 2018, representatives of Central African Forest Commission (COMIFAC) member countries selected a list of topics to be addressed in forthcoming policy analysis papers. One of the topics relates to the financing of the forestry and environment sectors of Central Africa (CA), especially funds received from international sources over the last decade. This topic is also part of the Renforcement et Institutionnalisation de l'Observatoire des Forêts d'Afrique Centrale (RIOFAC) project, funded by the European Union. RIOFAC is designed to support the Central African Forests Commission (OFAC) in its efforts to reinforce national capacity to collect, analyse and disseminate information for decision making on forest and forest-related sectors.

The Congo Basin has the second largest rainforest, after the Amazon forest in Brazil. The importance of the environmental services provided by rainforests at local, national and international levels, have focused global efforts on financing forests to fight climate change. Numerous funding initiatives have been established (and new ones are likely to emerge) to support the forest and environmental sectors. A study by Simula (2008) ${ }^{1}$ provides information on official development assistance (ODA) to CA from 2000 to 2007. This study shows 34 projects were internationally funded. Of these, 16 projects were funded by bilateral sources and 18 by multilateral sources. Rwanda received funding for the highest number

1 Simula M. 2008. Financing flows and needs to implement the non-legally binding instrument on all types of forests. Prepared for The Advisory Group on Finance of The Collaborative Partnership on Forests. of projects (8 projects), followed by Cameroon ( 7 projects), and the Democratic Republic of Congo (DRC) and Gabon (5 projects each). Germany was the highest bilateral donor. The Global Environmental Facility (GEF) was the highest multilateral donor, followed by the International Tropical Timber Organization (ITTO).

\subsection{Objectives and scope of study}

The objective of this study was to map out international funding flows, which will support the forest and environmental sectors in CA and will serve as background paper for the OFAC. The scope of this study includes: (a) the presentation and analysis of financing flows directed to CA over the last decade in support of nature conservation, sustainable forest management and climate change. The analysis includes both multilateral and bilateral sources (e.g. EU, Germany, France, Norway); (b) the presentation of themes or areas covered by the current financing flows and the identification of possible imbalances and gaps; (c) comparative analyses of financing flows to $\mathrm{CA}$ and those directed to Tropical America (Amazon Basin) and Tropical Asia (Southeast Asia); and (d) identification of needs and opportunities for financing the forest and environmental sectors of CA.

\subsection{Organization of the report}

The report consists of four sections. Section 1 introduces the study. Section 2 describes the methodology used. Section 3 considers funding flows to support forest and environmental sectors, and Section 4 concludes the report. 


\section{Methodology}

\subsection{Study approach}

The study approach is outlined in Figure 1. Desk research included a literature review and identification of data sources (OECD statistics ${ }^{2}$ and annual reports of the $\mathrm{ITTO}^{3}$ ). The flow analysis focused on donors, recipients, areas

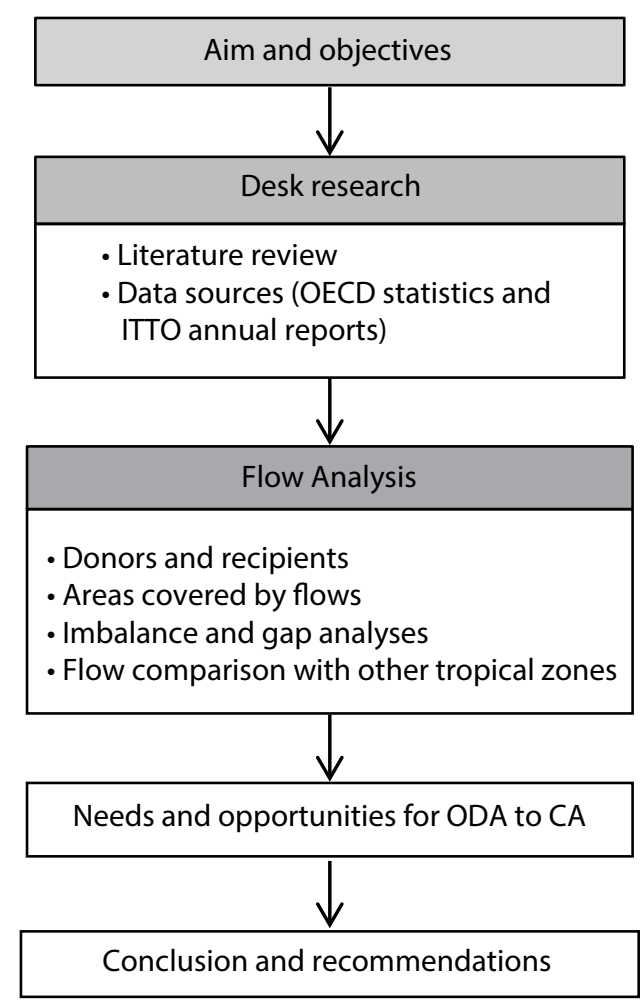

Figure 1. Study approach

2 [OECD] Organisation for Economic Co-operation and Development. 2017. Creditor Reporting System. Paris: OECD. Accessed 17 February 2017. https://stats.oecd.org/Index. aspx?DataSetCode=CRS1

3 [ITTO] International Tropical Timber Organization. n.d. Annual reports. Yokohama, Japan: ITTO. https://www.itto. int/annual_report/ covered, imbalances and gaps, and comparison of flows to CA with those to other tropical zones (Amazon Basin and Southeast Asia). Key findings helped to identity the needs and opportunities for financing the forest and environmental sectors in CA.

\subsection{Data and its sources}

OECD data were extracted for 10 years, 20082017. The flows to forestry sector were divided into six sub-sectors and those to the environment sector were divided seven sub-sectors (Table 1). The data include both bilateral flows from Development Assistance Committee (DAC) members and multilateral institutions.

The ITTO data were extracted from annual reports from 2008 to 2017, based on projects that were financed or approved for each year. These projects are classified by ITTO under different themes and focus areas. To harmonize the two datasets, the ITTO data were first classified under into 11 focus areas, and then grouped under the OECD focus areas (Table 2).

\subsection{Methodological limitations}

The OECD reports flow data as a commitment or disbursement by DAC members. The disbursement data may not be complete and updated for all donors. For this reason, we followed the method of Simula $(2008)^{4}$ and used commitment data rather than disbursement.

4 Simula M. 2008. Financing flows and needs to implement the non-legally binding instrument on all types of forests. Prepared for The Advisory Group on Finance of The Collaborative Partnership on Forests. 
Table 1. Areas covered by flows

\begin{tabular}{ll}
\hline Forestry & Environment \\
\hline Forestry research & Environmental policy and administrative management \\
Forest education or training & Flood prevention or control \\
Forestry development & Biodiversity \\
Forestry policy and administrative management & Biosphere protection \\
Forestry service & Environmental education or training \\
Fuelwood or charcoal & Environmental research \\
& Site preservation \\
\hline
\end{tabular}

Table 2. ITTO focus areas grouped under OECD focus areas

\begin{tabular}{ll}
\hline OECD focus areas & ITTO focus areas \\
\hline Forestry policy and administrative management & Forest law enforcement \\
& Forest communities \\
& Forest governance \\
Forestry development & Forest management \\
& Reduce deforestation \\
& Forest industries \\
& Reduce wildfires \\
& Market intelligence \\
Biosphere protection & Forest markets \\
Biodiversity & Payments for environmental services \\
\hline
\end{tabular}




\section{Funding flows to support forest and environmental sectors in Central Africa}

\subsection{Analysis of funding flows}

\subsubsection{Overview of funding flows}

The total forestry and environmental ODA (FEODA) flow to CA was approximately USD 1.7 billion over the period 2008-2017 (Table 3, see also Appendix 2). Of this, the bilateral FEODA and multilateral FEODA accounted for $52.5 \%$ and $47.5 \%$, respectively. The environmental ODA (EODA) flows to CA totaled USD 1.3 billion, equivalent to $79 \%$ of the total FEODA. From 2008 to 2017, the total FEODA fluctuated and peaked in 2015 at USD 315 million, declining in 2016 and 2017 to USD 106 million and USD 101 million, respectively (Figure 2).

\subsubsection{Flow types and sources}

Figure 3 shows trends in bilateral and multilateral FEODAs. These fluctuated over the period 20082017. The bilateral component peaked in 2013 at
USD 172 million and multilateral peaked in 2015 at USD 184 million. Since 2015, both flow types have declined.

Figure 4 shows the share of total FEODA by donor over 2008-2017 (only donors with share $>1 \%$ are included). The top five bilateral and multilateral donors were Germany (25\% of total FEODA), EU (19\%), GEF (11\%), United States (10\%) and the World Bank (9\%). See also Appendix 3 for a complete list of donors.

Figure 5 shows the shares of bilateral FEODA over the period 2008-2017. The top five donors were Germany ( $47 \%$ of total bilateral FEODA), United States (19\%), France (9\%), Japan (6\%) and Sweden (4\%). Finland and Denmark did not provide FEODA to CA in the period 2008-2017. Figure 6 gives shares of multilateral FEODA over the period 2008-2017. The top five donors were EU ( $41 \%$ of total multilateral FEODA), GEF (23\%), the World Bank (19\%), Climate Investment Fund (CIF) (7\%), and African

Table 3. Forest and environmental flows to CA, million USD

\begin{tabular}{lrrrrrrrrrrrr}
\hline Flow Type & 2008 & 2009 & 2010 & 2011 & 2012 & 2013 & 2014 & 2015 & 2016 & 2017 & Total & Share, \% \\
\hline \multicolumn{1}{l}{ Total CA FODA } & & & & & & & & & & & \\
\hline Bilateral & 13.5 & 11.0 & 36.1 & 11.2 & 9.4 & 12.3 & 9.1 & 13.1 & 15.3 & 37.6 & 168.5 & 9.9 \\
Multilateral & 9.2 & 40.1 & 6.6 & 24.3 & 14.9 & 24.8 & 33.8 & 6.2 & 16.8 & 17.9 & 194.7 & 11.5 \\
Sub-total & 22.7 & 51.1 & 42.7 & 35.5 & 24.3 & 37.1 & 42.9 & 19.3 & 32.1 & 55.5 & 363.3 & 21.4 \\
\hline Total CA EODA & & & & & & & & & & & & \\
\hline Bilateral & 53.3 & 44.2 & 41.4 & 55.9 & 71.6 & 159.3 & 44.0 & 117.4 & 112.7 & 21.6 & 721.2 & 42.5 \\
Multilateral & 75.0 & 38.0 & 17.9 & 58.3 & 40.3 & 66.4 & 19.3 & 177.7 & 95.0 & 23.7 & 611.5 & 36.1 \\
Sub-total & 128.3 & 82.1 & 59.2 & 114.2 & 111.8 & 225.7 & 63.3 & 295.1 & 207.7 & 45.3 & 1332.7 & 78.6 \\
\hline Total FEODA & & & & & & & & & & & \\
\hline Bilateral & 66.8 & 55.2 & 77.5 & 67.1 & 81.0 & 171.5 & 53.0 & 130.5 & 128.0 & 59.2 & 889.8 & 52.5 \\
Multilateral & 84.2 & 78.1 & 24.4 & 82.6 & 55.2 & 91.2 & 53.1 & 183.9 & 111.8 & 41.7 & 806.2 & 47.5 \\
Grand Total & 151.0 & 133.2 & 101.9 & 149.7 & 136.1 & 262.7 & 106.2 & 314.5 & 239.8 & 100.8 & 1696.0 & 100 \\
\hline
\end{tabular}




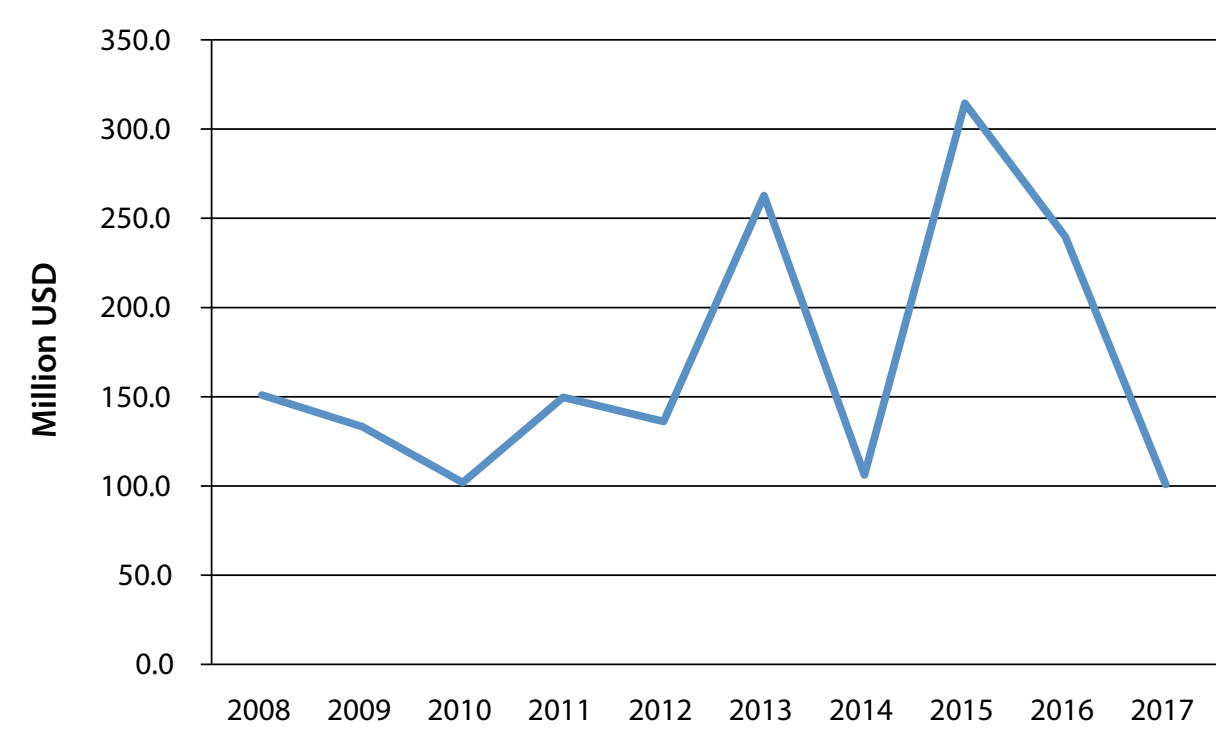

Figure 2. Trends in total forest and environmental flows

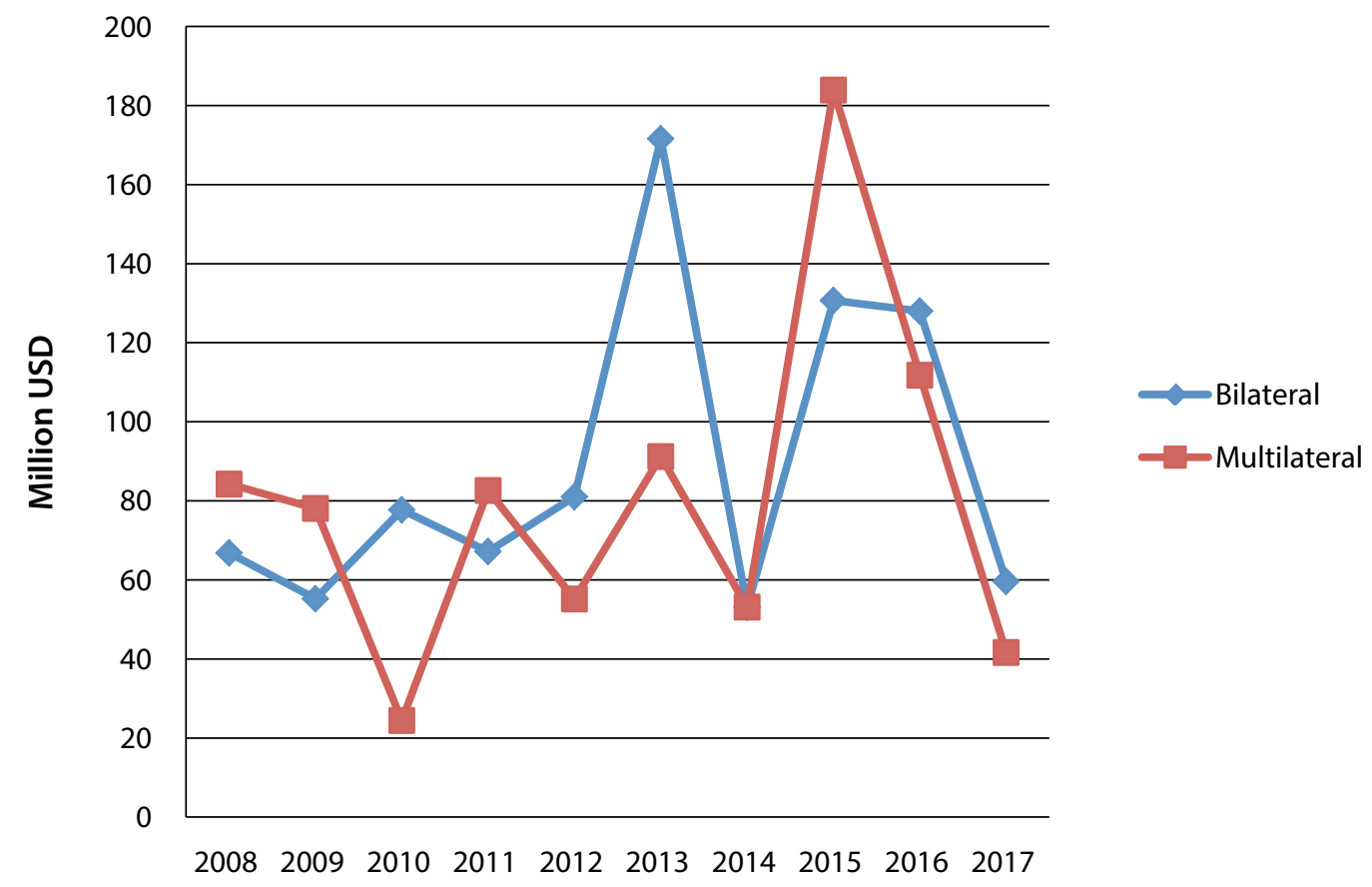

Figure 3. Trends in bilateral and multilateral FEODA, 2008-2017

Development Bank (AfDB) (5\%). Ireland had the lowest share $(0.03 \%)$. The Green Climate Fund (GCF) and Adaptation Fund did not provide FEODA to CA in the period 2008-2017.

\subsubsection{Recipients of FEODA in Central Africa}

Figure 7 shows the recipients of total FEODA in CA during the period 2008-2017 (see also Appendix 4). The top five recipients of the total
FEODA were DRC ( $40 \%$ of the total FEODA), Chad (17\%), Cameroon (14\%), Rwanda (9\%) and Gabon (7\%). Central African Republic (CAR) and Congo accounted for $4 \%$ each. Equatorial Guinea and Sao Tome and Principe accounted for less than $1 \%$ of the total FEODA individually, the lowest share $(0.3 \%)$ recorded by Equatorial Guinea.

Figure 8 shows the recipients of bilateral and multilateral FEODA (see also Appendices 5 


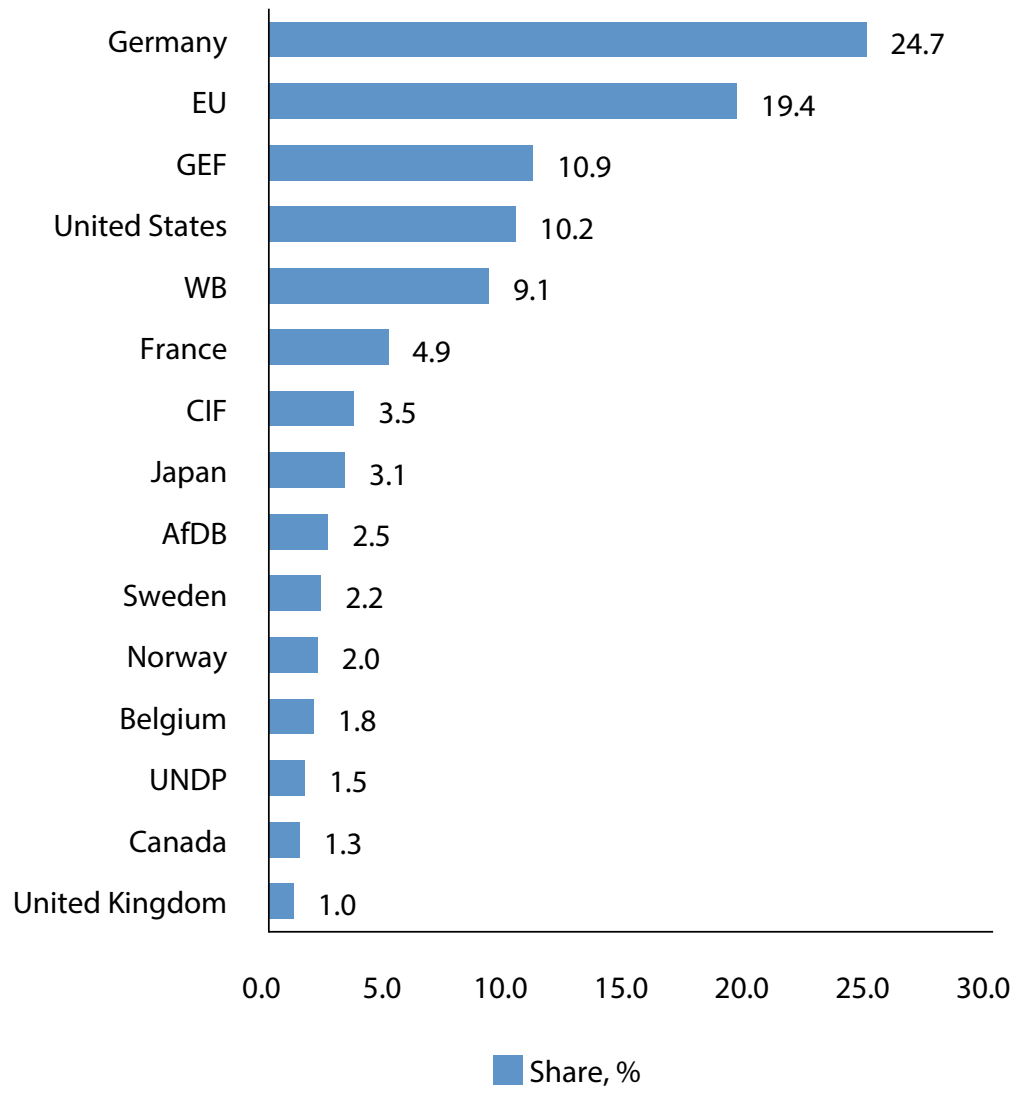

Figure 4. Share of total FEODA by donor

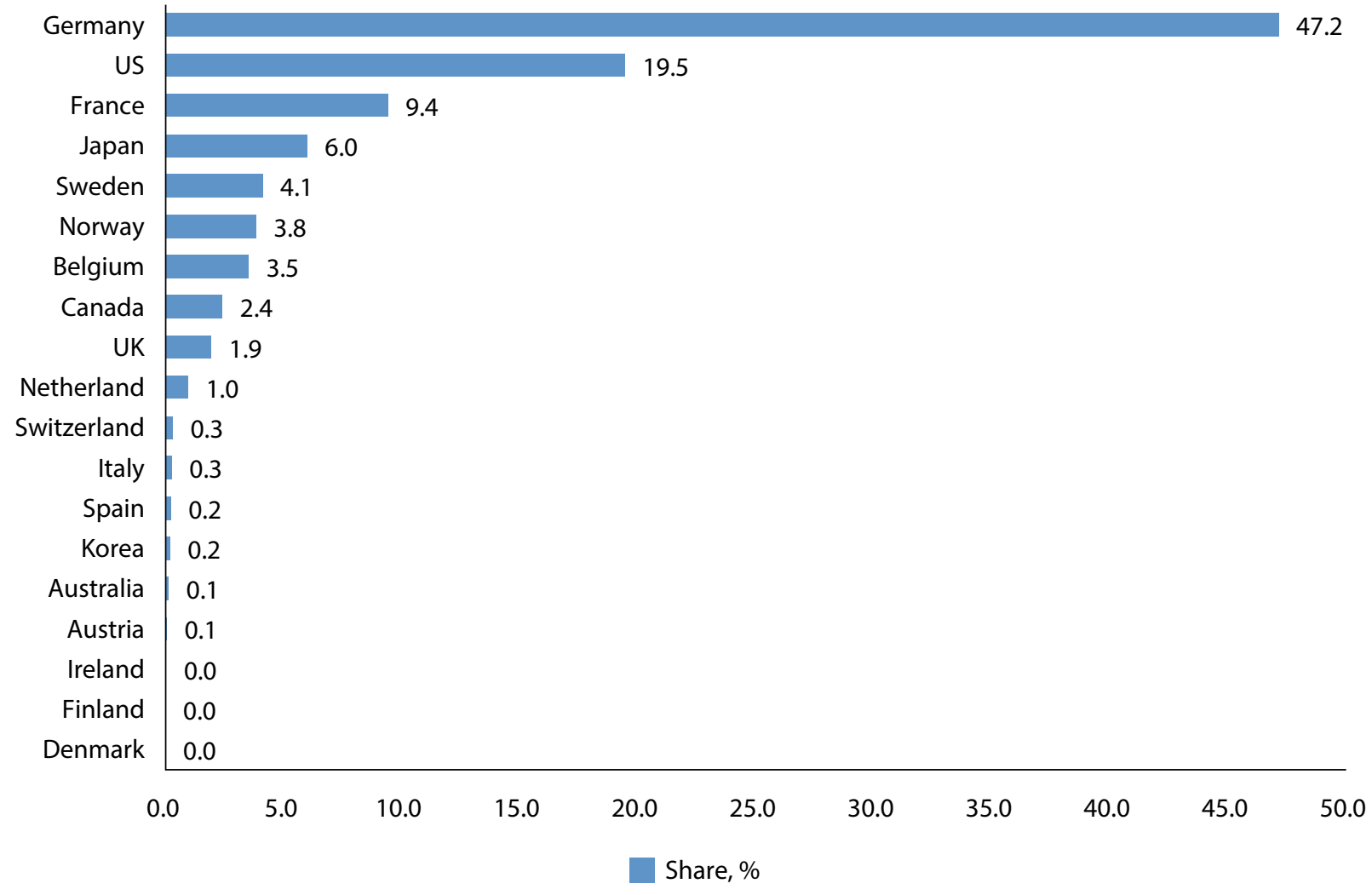




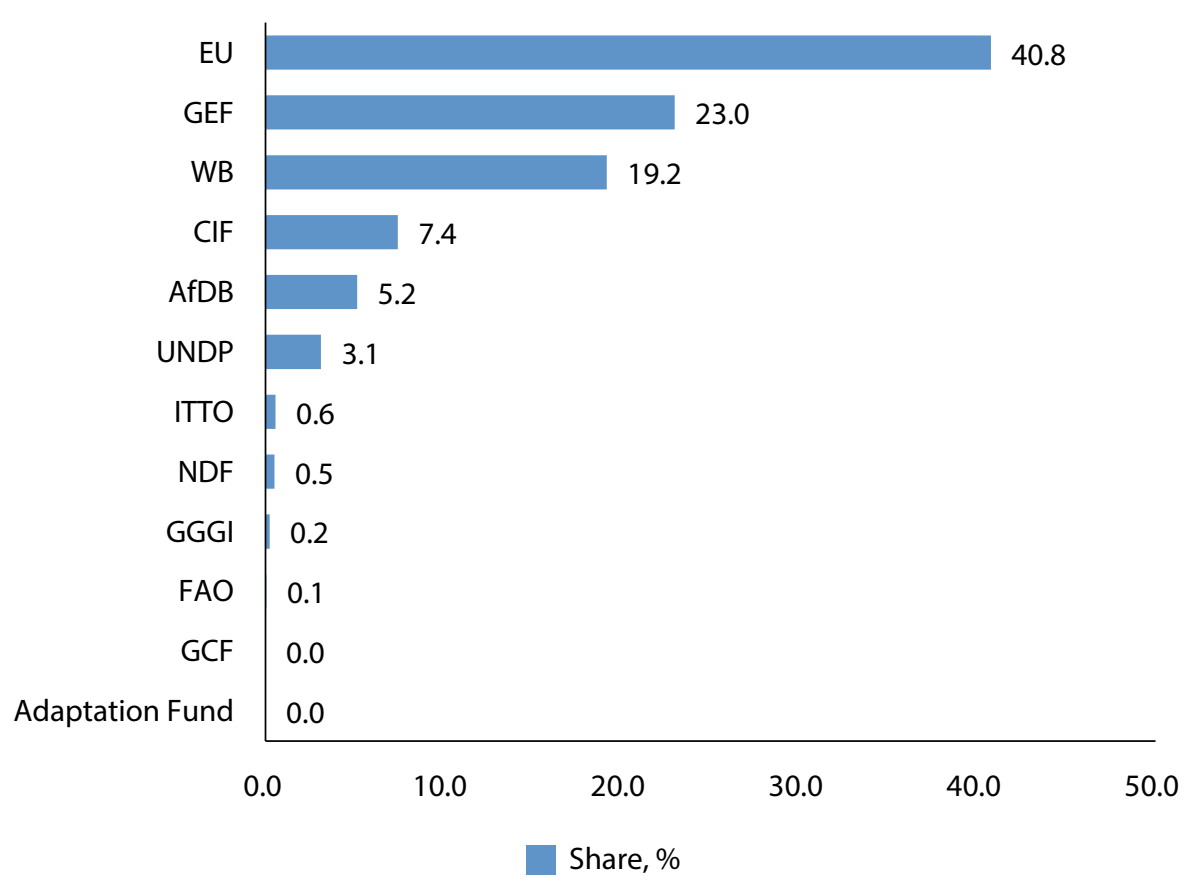

Figure 6. Share of multilateral FEODA by donor, 2008-2017

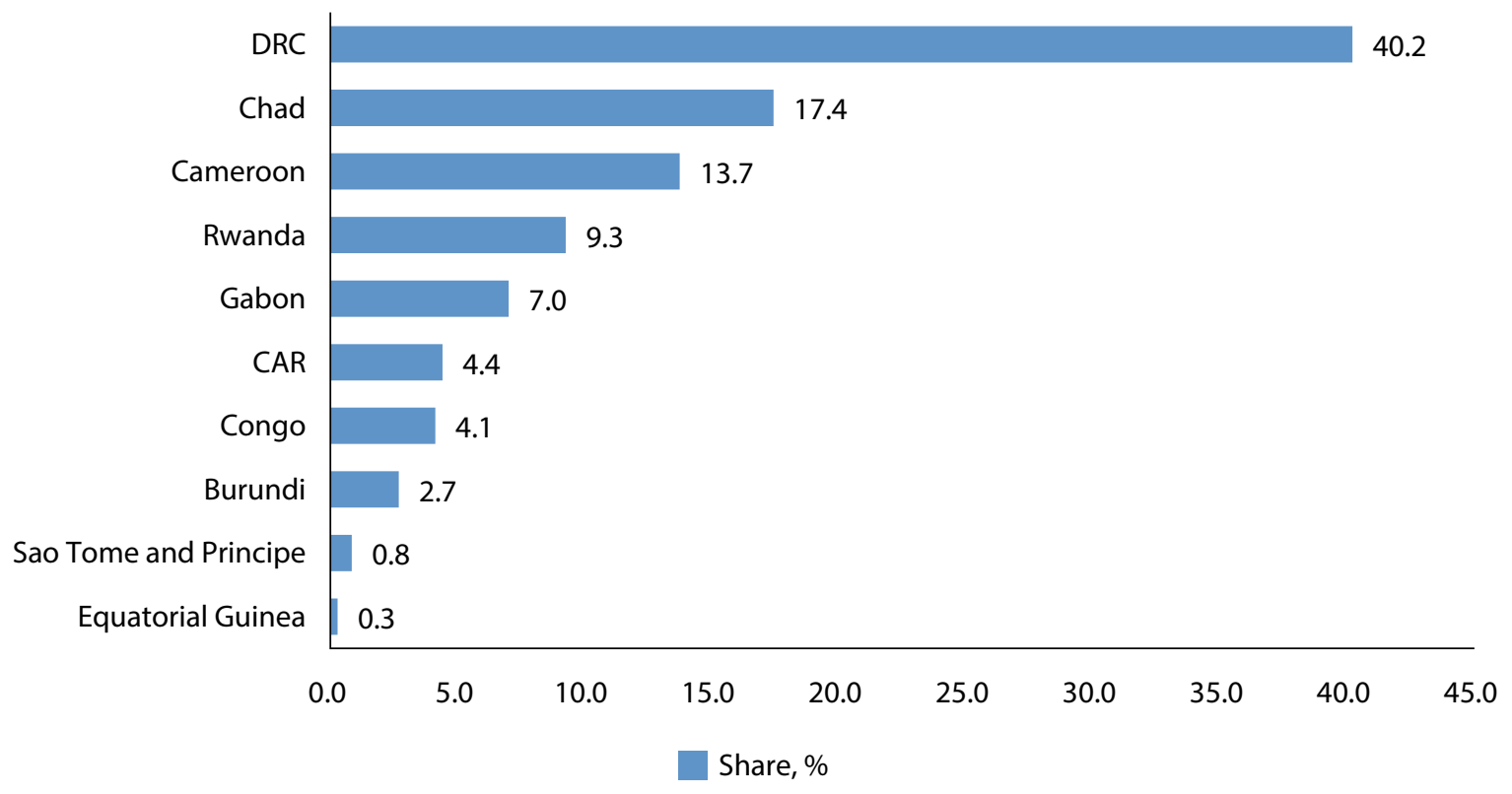

Figure 7. Recipients of FEODA in CA, 2008-2017

and 6). The top five recipients of bilateral FEODA were DRC (34\% of the total bilateral FEODA), Chad (21\%), Cameroon (15\%), Rwanda (11\%) and Gabon (11\%). The top five recipients of multilateral FEODA were DRC ( $47 \%$ of total multilateral FEODA), Chad (14\%), Cameroon (12\%), Rwanda (7\%) and Congo (6\%).

Equatorial Guinea and Sao Tome and Principe accounted for the lowest share $(0.1 \%)$ of the multilateral and bilateral FEODA, respectively. 


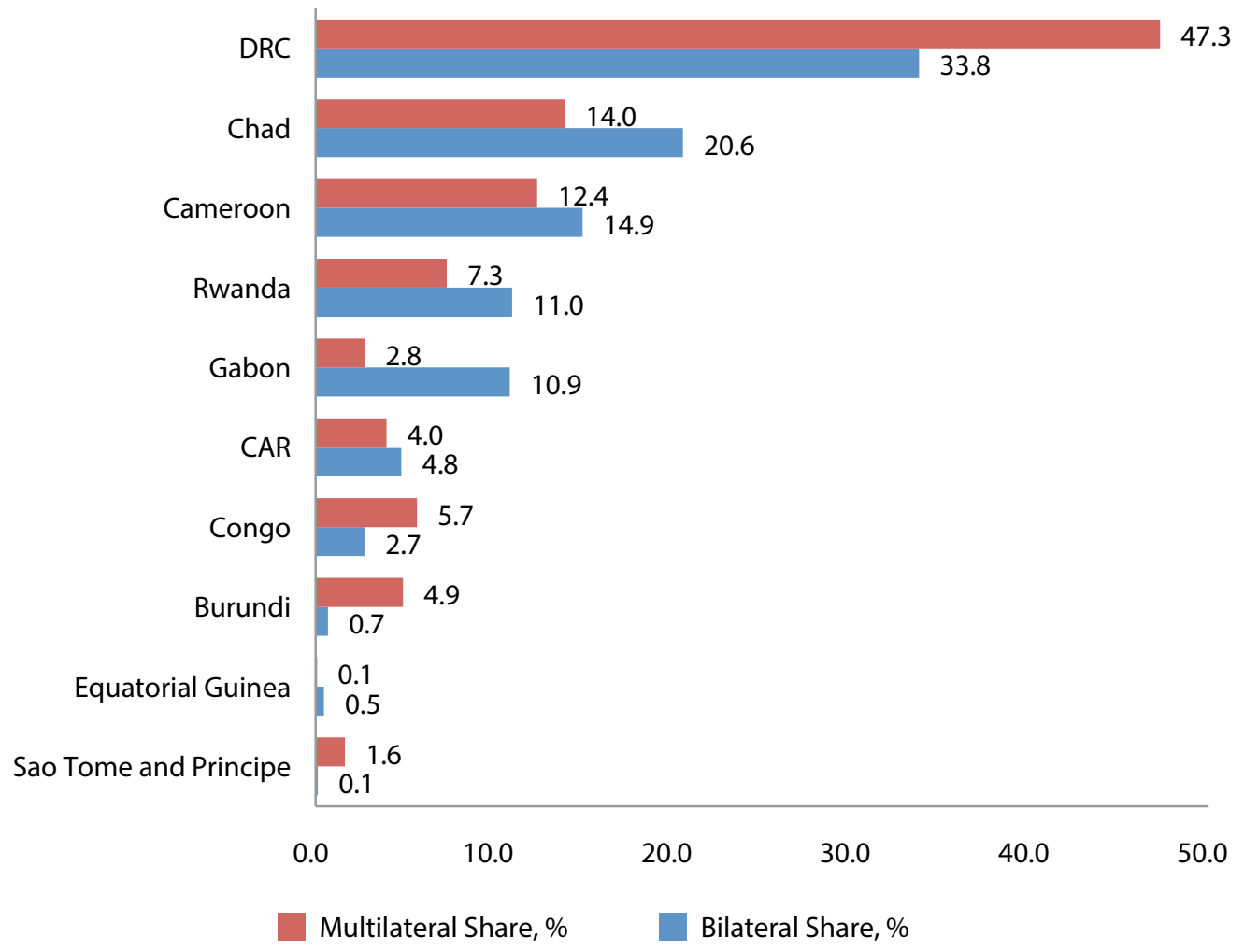

Figure 8. Recipients of bilateral and multilateral FEODA in CA, 2008-2017

\subsubsection{Areas/sub-sectors covered by flows}

Figure 9 shows areas covered by total FEODA during 2008-2017 (see also Appendix 7). The top five areas covered by flows were biodiversity ( $27 \%$ of the total FEODA in CA), environmental policy and administrative management $(26 \%)$, forestry policy and administrative management (15\%), environmental research $(11 \%)$, and biosphere protection (10\%). The other sub-sectors accounted for less than $5 \%$ each, the lowest recorded for forestry research $(0.1 \%)$.

Areas covered by bilateral FEODA in 2008-2017 are presented in Figure 10 (see also Appendix 8). The top five areas or sub-sectors covered by the bilateral flows included biodiversity (32\%), environmental policy and administrative management (22\%), environmental research $(21 \%)$, forest policy and administrative management (12\%), and forest development (5\%). The other sub-sectors accounted for less than $5 \%$ each, the lowest recorded for forestry research $(0.2 \%)$.
For the multilateral FEODA (Figure 11, see also Appendix 9), the top five areas covered included environmental policy and administrative management $(31 \%)$, biodiversity $(20 \%)$, biosphere protection (19\%), forest policy and administrative management $(18 \%)$, and forest development (6\%). Forestry service and environmental education or training accounted for the lowest share less than $0.03 \%$ each. Sub-sectors that did not receive multilateral flows included environmental research, forestry education and training, fuelwood and charcoal, and forestry research.

\subsection{Imbalances and gaps in flows}

\subsubsection{Development of total FEODA}

The total FEODA of USD 150 million in 2008 plummeted to USD 100 million in 2017 (Figure 12). Both bilateral and multilateral FEODAs exhibited similar patterns. The former peaked in 2013 at USD 172 million and the latter peaked in 2015 at USD 184 million. Bilateral and multilateral FEODAs have decreased since 2015. 


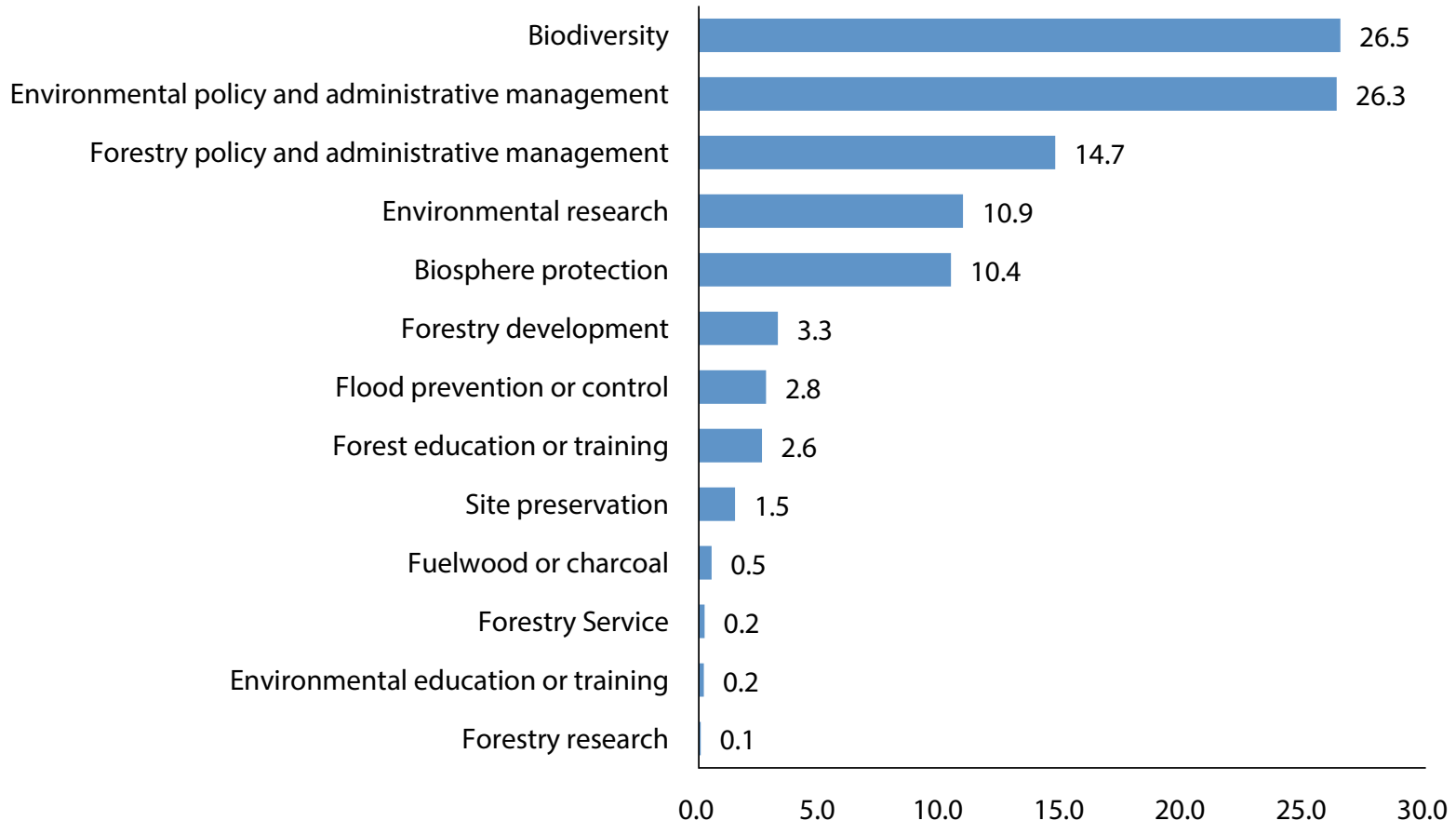

Share, $\%$

Figure 9. Areas covered by FEODA

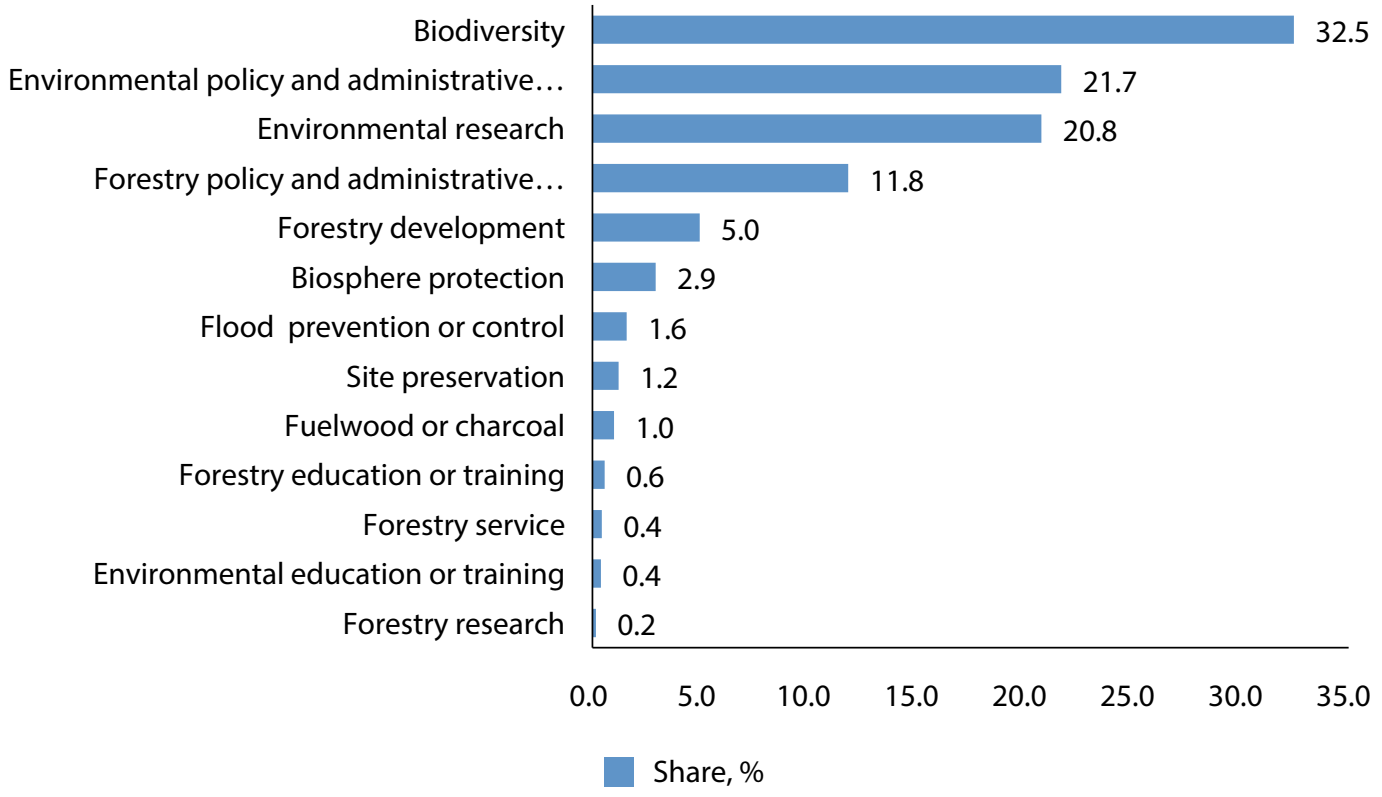

Figure 10. Areas covered by bilateral FEODA, 2008-2017

\subsubsection{Areas covered by FEODA}

The top five areas covered by total FEODA accounted for $89 \%$ of the total FEODA value (USD 1.7 billion) during the period 2008-2017.
Forestry research had the lowest share $(0.1 \%)$. Environmental education and training, and forestry service accounted for $0.2 \%$ each. Forestry education and training, and fuelwood and charcoal accounted for $0.3 \%$ and $0.5 \%$, respectively. 
Environmental policy and administrative... Biodiversity Biosphere protection Forestry policy and administrative management Forestry development Flood prevention or control Site preservation Forestry service Environmental education or training Environmental research Forestry education or training Fuelwood or charcoal Forestry research

$$
0.0
$$
0.0

Share, \%

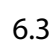

$\begin{array}{lllllll}.0 & 10.0 & 15.0 & 20.0 & 25.0 & 30.0 & 35.0\end{array}$

Figure 11. Areas covered by multilateral FEODA, 2008-2017

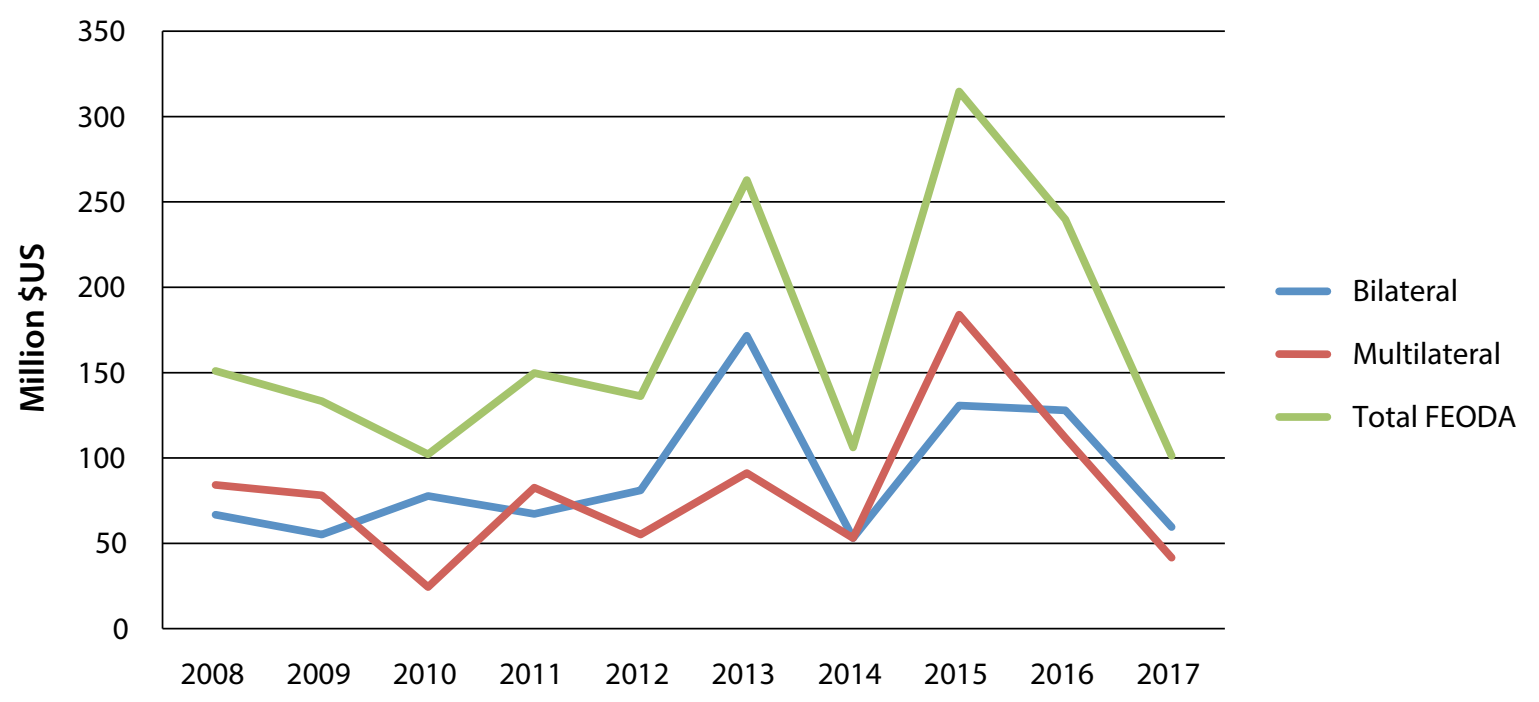

Figure 12. Trends in FEODA, 2008-2017

\subsubsection{Bilateral and multilateral donor presence and absence}

Table 4 shows the bilateral and multilateral donor presence and their ODA over the period 2008-2017. Donor presence is a measure of the number of donors to each recipient country. Rwanda and Cameroon recorded the highest number of bilateral donors (15 each). Equatorial Guinea had the lowest number of bilateral donors (5).

According to the number of donors identified in this study, donor absence is the non-provision of ODA by a donor. Equatorial Guinea had the highest number of bilateral donor absences (14); followed by Sao Tome and Principe (12) and Chad and Gabon (11 each) Cameroon and Rwanda recorded the lowest number of donor absence ( 4 each). Donors that were absent in Equatorial Guinea were Australia, Austria, Belgium, Denmark, Finland, France, Ireland, Italy, Korea, Netherlands, Norway, Sweden, Switzerland and the UK. Donors that were absent in Sao Tome included Austria, Belgium, Denmark, Finland, Germany, Ireland, Italy, South Korea, the Netherlands, Norway, Sweden and Switzerland. 
Table 4. Bilateral and multilateral donor presence and absence in CA

\begin{tabular}{lcccccccc}
\hline Recipient & \multicolumn{4}{c}{ Bilateral } \\
\cline { 2 - 9 } & $\begin{array}{c}\text { Donor } \\
\text { presence }\end{array}$ & $\begin{array}{c}\text { Donor } \\
\text { absence }\end{array}$ & $\begin{array}{c}\text { Number } \\
\text { of ODAs }\end{array}$ & $\begin{array}{c}\text { Share, } \\
\%\end{array}$ & $\begin{array}{c}\text { Donor } \\
\text { presence }\end{array}$ & $\begin{array}{c}\text { Donor } \\
\text { absence }\end{array}$ & $\begin{array}{r}\text { Number } \\
\text { of ODAs }\end{array}$ & $\begin{array}{c}\text { Share, } \\
\%\end{array}$ \\
\hline Burundi & 9 & 10 & 30 & 6.4 & 3 & 9 & 15 & 7.9 \\
Cameroon & 15 & 4 & 80 & 17.0 & 6 & 6 & 30 & 15.9 \\
CAR & 9 & 10 & 29 & 6.2 & 5 & 7 & 18 & 9.5 \\
Chad & 8 & 11 & 41 & 8.7 & 5 & 7 & 22 & 11.6 \\
Congo & 10 & 9 & 45 & 9.6 & 7 & 5 & 26 & 13.8 \\
DRC & 14 & 5 & 90 & 19.1 & 6 & 6 & 29 & 15.3 \\
Equatorial Guinea & 5 & 14 & 21 & 4.5 & 2 & 10 & 8 & 4.2 \\
Gabon & 8 & 11 & 38 & 8.1 & 5 & 7 & 15 & 7.9 \\
Rwanda & 15 & 4 & 83 & 17.7 & 7 & 5 & 21 & 11.1 \\
Sao Tome and Principe & 7 & 12 & 13 & 2.8 & 3 & 9 & 5 & 2.6 \\
\hline Total CA & & & 470 & 100 & & & 189 & 100 \\
\hline
\end{tabular}

Table 5. Bilateral frequency of funding and no funding by year

\begin{tabular}{lcccccccccccc}
\hline Recipient & 2008 & $\mathbf{2 0 0 9}$ & $\mathbf{2 0 1 0}$ & $\mathbf{2 0 1 1}$ & $\mathbf{2 0 1 2}$ & $\mathbf{2 0 1 3}$ & $\mathbf{2 0 1 4}$ & $\mathbf{2 0 1 5}$ & $\mathbf{2 0 1 6}$ & $\mathbf{2 0 1 7}$ & Total $\begin{array}{c}\text { Annual } \\
\text { Average }\end{array}$ \\
\hline Burundi & 3 & 5 & 2 & 4 & 3 & 3 & 5 & 3 & 2 & 0 & 30 & 3 \\
Cameroon & 6 & 7 & 8 & 8 & 8 & 9 & 10 & 8 & 7 & 9 & 80 & 8 \\
CAR & 3 & 4 & 2 & 4 & 3 & 4 & 3 & 2 & 3 & 1 & 29 & 3 \\
Chad & 3 & 5 & 5 & 4 & 3 & 3 & 6 & 5 & 4 & 3 & 41 & 4 \\
Congo & 3 & 4 & 2 & 6 & 4 & 6 & 6 & 4 & 7 & 3 & 45 & 5 \\
DRC & 7 & 8 & 10 & 9 & 8 & 10 & 9 & 10 & 9 & 10 & 90 & 9 \\
Equatorial Guine & 1 & 4 & 3 & 2 & 2 & 2 & 1 & 3 & 2 & 1 & 21 & 2 \\
Gabon & 3 & 4 & 3 & 5 & 3 & 4 & 4 & 4 & 4 & 4 & 38 & 4 \\
Rwanda & 7 & 7 & 10 & 9 & 8 & 10 & 12 & 7 & 5 & 8 & 83 & 8 \\
Sao Tome and & 1 & 2 & 0 & 0 & 1 & 2 & 2 & 0 & 3 & 2 & 13 & 1 \\
Principe & $\mathbf{3}$ & $\mathbf{5 0}$ & $\mathbf{4 5}$ & $\mathbf{5 1}$ & $\mathbf{4 3}$ & $\mathbf{5 3}$ & $\mathbf{5 8}$ & $\mathbf{4 6}$ & $\mathbf{4 6}$ & $\mathbf{4 1}$ & $\mathbf{4 7 0}$ & $\mathbf{4 7}$ \\
\hline Total CA & & & & & & & & & & & &
\end{tabular}

Seventeen bilateral donors made 470 bilateral ODA grants to CA during 2008-2017. The DRC received 90 ODA grants, equivalent to $19 \%$ of the total number of bilateral ODA grants. It was followed by Rwanda (18\%) and Cameroon (17\%). These countries accounted for a combined share of $54 \%$ of the total number of bilateral ODA grants to CA. Burundi, CAR, Chad, Congo and Gabon received between $5 \%$ and $10 \%$ of the total number of bilateral ODA grants. Equatorial Guinea and Sao Tome and Principe received less than 5\%.
Rwanda and Congo had the largest number of multilateral donors (7 each). Equatorial Guinea had the lowest number of multilateral donors (2).

Equatorial Guinea recorded the highest number multilateral donor absences (10). Donors that were absent included the Adaptation Fund, AfDB, CIF, EU, Food and Agriculture Organization (FAO), GCF, Global Green Growth Institute (GGGI), ITTO, Nordic Development Fund (NDF) and the World Bank. 
Table 6. Multilateral frequency of funding by year

\begin{tabular}{lcccccccccccc}
\hline Recipient & 2008 & $\mathbf{2 0 0 9}$ & $\mathbf{2 0 1 0}$ & $\mathbf{2 0 1 1}$ & $\mathbf{2 0 1 2}$ & $\mathbf{2 0 1 3}$ & $\mathbf{2 0 1 4}$ & $\mathbf{2 0 1 5}$ & $\mathbf{2 0 1 6}$ & $\mathbf{2 0 1 7}$ & Total & $\begin{array}{c}\text { Yearly } \\
\text { Average }\end{array}$ \\
\hline Burundi & 1 & 2 & 0 & 2 & 2 & 2 & 2 & 2 & 1 & 1 & 15 & 1.5 \\
Cameroon & 3 & 3 & 4 & 2 & 4 & 4 & 2 & 4 & 2 & 2 & 30 & 3 \\
CAR & 1 & 2 & 2 & 2 & 2 & 4 & 1 & 0 & 3 & 1 & 18 & 1.8 \\
Chad & 3 & 2 & 2 & 2 & 1 & 4 & 1 & 3 & 3 & 1 & 22 & 2.2 \\
Congo & 2 & 2 & 2 & 2 & 4 & 3 & 2 & 2 & 4 & 3 & 26 & 2.6 \\
DRC & 3 & 4 & 2 & 3 & 2 & 3 & 4 & 3 & 3 & 2 & 29 & 2.9 \\
Equatorial Guinea & 1 & 2 & 1 & 1 & 2 & 1 & 0 & 0 & 0 & 0 & 8 & 0.8 \\
Gabon & 0 & 2 & 1 & 1 & 2 & 3 & 1 & 1 & 2 & 2 & 15 & 1.5 \\
Rwanda & 1 & 1 & 2 & 2 & 2 & 3 & 2 & 1 & 4 & 3 & 21 & 2.1 \\
Sao Tome and & 1 & 0 & 0 & 1 & 1 & 2 & 0 & 0 & 0 & 0 & 5 & 0.5 \\
Principe & 16 & $\mathbf{2 0}$ & $\mathbf{1 6}$ & $\mathbf{1 8}$ & $\mathbf{2 2}$ & $\mathbf{2 9}$ & $\mathbf{1 5}$ & $\mathbf{1 6}$ & $\mathbf{2 2}$ & $\mathbf{1 5}$ & $\mathbf{1 8 9}$ & $\mathbf{1 8 . 9}$ \\
\hline Total CA & & & & & & & & & & & &
\end{tabular}

Twelve multilateral donors contributed 189 multilateral ODA grants to CA during 2008-2017. Cameroon had the highest number (30), equivalent to $16 \%$ of the total multilateral ODA.

Table 5 shows the number of bilateral ODA grants received per year by recipient countries. In 2014, the CA received the highest number of bilateral ODA grants (58) and the lowest number (37) in 2008. On average, the DRC received 9 bilateral ODA grants per year, followed by Cameroon and Rwanda (8 each), Congo (5), Chad and Gabon (4 each), Burundi and CAR (3 each), Equatorial Guinea (2) and Sao Tome and Principe (1).

Table 6 gives the number of multilateral ODA grants received per year by recipient country in CA. In 2013, CA received the highest number of multilateral ODAs (29) and the lowest number (15) in 2014 and 2017. On average, Cameroon, Congo and the DRC received about three multilateral ODAs, followed by Burundi, CAR, Chad, Gabon and Rwanda receiving 2 each, and Equatorial Guinea and Sao Tome and Principe receiving 1 each. Burundi, CAR, Gabon and Equatorial Guinea did not receive multilateral ODA in 2010, 2015, 2008 and from 2014 to 2017 respectively. Sao Tome and Principe equally did not receive multilateral ODA in 2009, 2010 and from 2014 to 2017.

\subsection{Comparative study of funding flows in CA and other tropical zones}

\subsubsection{Funding flow levels}

The total FEODA to the three tropical zones (or total tropical FEODA) over the period 2008-2017 was USD 14.9 billion (Table 7). The funding flows to CA totaled USD 1.7 billion, equivalent to $11 \%$ of the total tropical FEODA. Amazon Basin received USD 5.1 billion, equivalent to $34 \%$ of the total tropical FEODA. Southeast Asia recorded USD 8.1 billion, equivalent to $55 \%$ of the total tropical FEODA. The total FEODA to CA is the lowest of the three tropical zones. The difference between bilateral and multilateral funding flow levels is large for Amazon Basin and Southeast Asia, but smaller for CA $(5 \%)$.

\subsubsection{Financing area coverage}

Table 8 presents the sub-sectors covered by the bilateral ODA during the period 2008-2017. The top five areas covered by the flows differ across tropical zones. In CA, the main areas covered by flows were biodiversity (33\% of the total bilateral ODA to CA), environmental policy and administrative management $(22 \%)$, environmental research (21\%), forestry policy and administrative management (12\%) and forest development (5\%). 
Table 7. Forest and environmental flows to tropical zones, 2008-2017

\begin{tabular}{|c|c|c|c|c|c|c|c|c|c|c|c|c|}
\hline Flow Type & 2008 & 2009 & 2010 & 2011 & 2012 & 2013 & 2014 & 2015 & 2016 & 2017 & Total & Share, $\%$ \\
\hline \multicolumn{13}{|l|}{$C A$} \\
\hline Bilateral & 66.8 & 55.2 & 77.5 & 67.1 & 81.0 & 171.5 & 53.0 & 130.5 & 128.0 & 59.2 & 889.8 & 6.0 \\
\hline Multilateral & 84.2 & 78.1 & 24.4 & 82.6 & 55.2 & 91.2 & 53.1 & 183.9 & 111.8 & 41.7 & 806.2 & 5.4 \\
\hline Sub-Total & 151.0 & 133.2 & 101.9 & 149.7 & 136.1 & 262.7 & 106.2 & 314.5 & 239.8 & 100.8 & 1696.0 & 11.4 \\
\hline \multicolumn{13}{|c|}{ Amazon Basin } \\
\hline Bilateral & 151.1 & 273.9 & 574.3 & 415.8 & 387.7 & 327.2 & 393.6 & 776.9 & 511.7 & 432.6 & 4244.7 & 28.6 \\
\hline Multilateral & 37.8 & 79.9 & 45.5 & 37.3 & 135.1 & 92.2 & 43.1 & 75.9 & 144.7 & 120.3 & 811.8 & 5.5 \\
\hline Sub-Total & 188.9 & 353.8 & 619.8 & 453.1 & 522.8 & 419.5 & 436.6 & 852.7 & 656.3 & 552.8 & 5056.5 & 34.0 \\
\hline \multicolumn{13}{|c|}{ Southeast Asia } \\
\hline Bilateral & 658.2 & 781.6 & 1054.0 & 521.2 & 801.6 & 576.3 & 556.0 & 550.6 & 591.0 & 492.3 & 6582.8 & 44.3 \\
\hline Multilateral & 47.9 & 87.9 & 40.1 & 90.5 & 203.6 & 116.4 & 101.0 & 69.2 & 434.1 & 329.9 & 1520.5 & 10.2 \\
\hline Sub-Total & 706.2 & 869.5 & 1094.1 & 611.8 & 1005.2 & 692.7 & 657.0 & 619.8 & 1025.0 & 822.2 & 8103.4 & 54.5 \\
\hline \multicolumn{13}{|c|}{ Tropical Zones } \\
\hline Bilateral & 876.1 & 1110.7 & 1705.8 & 1004.2 & 1270.2 & 1075.1 & 1002.6 & 1458.0 & 1230.6 & 984.0 & 11717.2 & 78.9 \\
\hline Multilateral & 170.0 & 245.8 & 110.1 & 210.4 & 393.9 & 299.8 & 197.2 & 329.0 & 690.5 & 491.8 & 3138.6 & 21.1 \\
\hline Grand Total & 1046.0 & 1356.5 & 1815.8 & 1214.6 & 1664.1 & 1374.9 & 1199.8 & 1787.0 & 1921.1 & 1475.9 & 14855.8 & 100 \\
\hline
\end{tabular}


Table 8. Bilateral funding areas by topical zone

\begin{tabular}{|c|c|c|c|c|c|c|c|c|}
\hline CA & Total 2008-17 & Share, \% & Amazon Basin & Total 2008-17 & Share, \% & Southeast Asia & Total 2008-17 & Share, \% \\
\hline Biodiversity & 288.9 & 32.5 & $\begin{array}{l}\text { Environmental policy } \\
\text { and administrative } \\
\text { management }\end{array}$ & 2551.3 & 60.0 & $\begin{array}{l}\text { Environmental policy } \\
\text { and administrative } \\
\text { management }\end{array}$ & 3789.1 & 57.8 \\
\hline $\begin{array}{l}\text { Environmental policy and } \\
\text { administrative management }\end{array}$ & 193.0 & 21.7 & Biodiversity & 991.4 & 23.3 & $\begin{array}{l}\text { Flood prevention or } \\
\text { control }\end{array}$ & 1007.4 & 15.4 \\
\hline Environmental research & 184.9 & 20.8 & Biosphere protection & 196.3 & 4.6 & Biodiversity & 516.0 & 7.9 \\
\hline $\begin{array}{l}\text { Forestry policy and } \\
\text { administrative management }\end{array}$ & 105.3 & 11.8 & $\begin{array}{l}\text { Forestry policy } \\
\text { and administrative } \\
\text { management }\end{array}$ & 167.5 & 3.9 & $\begin{array}{l}\text { Forestry policy } \\
\text { and administrative } \\
\text { management }\end{array}$ & 475.5 & 7.2 \\
\hline Forestry development & 44.2 & 5.0 & Forestry development & 96.7 & 2.3 & Biosphere protection & 424.0 & 6.5 \\
\hline Biosphere protection & 26.0 & 2.9 & Environmental research & 87.6 & 2.1 & Forestry development & 179.5 & 2.7 \\
\hline Flood prevention or control & 14.1 & 1.6 & Site preservation & 70.0 & 1.6 & Environmental research & 84.6 & 1.3 \\
\hline Site preservation & 10.7 & 1.2 & $\begin{array}{l}\text { Flood prevention or } \\
\text { control }\end{array}$ & 58.9 & 1.4 & $\begin{array}{l}\text { Environmental } \\
\text { education and training }\end{array}$ & 29.0 & 0.4 \\
\hline Fuelwood and charcoal & 8.9 & 1.0 & $\begin{array}{l}\text { Environmental } \\
\text { education and training }\end{array}$ & 20.7 & 0.5 & Site preservation & 25.3 & 0.4 \\
\hline Forest education and training & 5.0 & 0.6 & Forestry service & 7.2 & 0.2 & Forestry service & 13.0 & 0.2 \\
\hline Forestry service & 3.8 & 0.4 & $\begin{array}{l}\text { Forest education and } \\
\text { training }\end{array}$ & 1.4 & 0.0 & Forestry research & 11.3 & 0.2 \\
\hline $\begin{array}{l}\text { Environmental education or } \\
\text { training }\end{array}$ & 3.5 & 0.4 & Forestry research & 1.0 & 0.0 & $\begin{array}{l}\text { Forest education and } \\
\text { training }\end{array}$ & 4.4 & 0.1 \\
\hline Forestry research & 1.4 & 0.2 & Fuelwood and charcoal & 0.0 & 0.0 & Fuelwood and charcoal & 0.0 & 0.0 \\
\hline Total & 889.8 & 100 & & 4249.9 & 100 & & 6559.0 & 100 \\
\hline
\end{tabular}


In the Amazon Basin, the top five areas covered were environmental policy and administrative management $(60 \%$ of the total bilateral ODA to Amazon Basin), Biodiversity (23\%), biosphere protection (5\%), forestry policy and administrative management $(4 \%)$, and forestry development (2\%).

In Southeast Asia, the top five areas covered were environmental policy and administrative management $(58 \%$ of the total bilateral ODA to Southeast Asia), flood prevention or control $(15 \%)$, biodiversity $(8 \%)$, forestry policy and administrative management $(7 \%)$ and biosphere protection $(7 \%)$.

The sub-sector that received the lowest bilateral flow in CA was forestry research (USD 1.4 million), equivalent to $0.2 \%$ of total bilateral ODA to CA. In the Amazon Basin, the lowest funding flow was for forestry research (USD 1 million), and there was no funding for neither fuelwood nor charcoal. In Southeast Asia, the area that received the lowest funding flow was forestry education and training (USD 4.4 million), equivalent to $0.4 \%$ of total bilateral ODA, and there was no funding for both fuelwood and charcoal.

Comparing the top five areas covered by bilateral flows in CA, the Amazon Basin and Southeast Asia, the common areas covered by bilateral flows are biodiversity, environmental policy and administrative management, and forestry policy and administrative management. Biodiversity ranked first for CA, second for the Amazon Basin and third for Southeast Asia. Environmental policy and administrative management ranked second for CA, first for Amazon Basin and Southeast Asia. Forestry policy and administrative management ranked fourth for CA, Amazon Basin and Southeast Asia.

Table 9 presents the areas that received multilateral ODA during the period 20082017. In CA, the top five topics covered by multilateral flows were environmental policy and administrative management $(31 \%$ of the total multilateral ODA to CA), biodiversity (20\%), biosphere protection (19\%), forestry policy and administrative management (18\%), and forestry development (6\%).
In the Amazon Basin, the top five topics covered by multilateral flows were biodiversity ( $40 \%$ of the total multilateral ODA to the Amazon Basin), environmental policy and administrative management (31\%), forestry policy and administrative management (13\%), flood prevention and control (8\%), and forestry development (4\%).

In Southeast Asia, the top five topics covered by multilateral flows were environmental policy and administrative management (33\%) of the total multilateral ODA to Southeast Asia), flood prevention and control (21\%), biodiversity (13\%), forestry policy and administrative management $(12 \%)$, and forestry development (10\%).

In $\mathrm{CA}$, the sub-sector that received the lowest multilateral funding was forestry service (USD 0.2 million). Environmental education and training, forestry research, fuelwood and charcoal, forestry education and training, and environmental research were not covered by multilateral ODA during the study period.

In the Amazon Basin, environmental education and training received the lowest funding (USD 0.3 million). Forestry research, forestry service, forestry education and training, and environmental research did not receive multilateral funding during the study period.

In Southeast Asia, site preservation received the lowest multilateral funding (USD 0.6 million). Forestry research, forestry service, fuelwood and charcoal and forestry education or training did not receive multilateral funding during the study period.

Comparing the top five areas covered by flows in CA, the Amazon Basin and Southeast Asia, the common areas are environmental policy and administrative management, biodiversity, forestry policy and administrative management, and forestry development. Environmental policy and administrative management ranked first for CA and Southeast Asia and second place for Amazon Basin. Biodiversity ranked first for Amazon Basin, second place for CA and third place for Southeast Asia. Forestry policy and administrative management ranked third for Amazon Basin and fourth for CA 
Table 9. Multilateral Funding Areas by Topical Zone

\begin{tabular}{|c|c|c|c|c|c|c|c|c|}
\hline CA & Total 2008-17 & Share, \% & Amazon Basin & Total 2008-17 & Share, \% & Southeast Asia & Total 2008-17 & Share, \% \\
\hline $\begin{array}{l}\text { Environmental policy and } \\
\text { administrative management }\end{array}$ & 253.3 & 31.4 & Biodiversity & 322.9 & 39.8 & $\begin{array}{l}\text { Environmental policy } \\
\text { and administrative } \\
\text { management }\end{array}$ & 506.9 & 33.3 \\
\hline Biodiversity & 160.1 & 19.9 & $\begin{array}{l}\text { Environmental policy } \\
\text { and administrative } \\
\text { management }\end{array}$ & 248.1 & 30.6 & $\begin{array}{l}\text { Flood prevention or } \\
\text { control }\end{array}$ & 319.4 & 21.0 \\
\hline Biosphere protection & 150.4 & 18.7 & $\begin{array}{l}\text { Forestry policy } \\
\text { and administrative } \\
\text { management }\end{array}$ & 104.0 & 12.8 & Biodiversity & 197.2 & 13.0 \\
\hline $\begin{array}{l}\text { Forestry policy and } \\
\text { administrative management }\end{array}$ & 144.1 & 17.9 & $\begin{array}{l}\text { Flood prevention or } \\
\text { control }\end{array}$ & 66.5 & 8.2 & $\begin{array}{l}\text { Forestry policy } \\
\text { and administrative } \\
\text { management }\end{array}$ & 183.0 & 12.0 \\
\hline Forestry development & 50.4 & 6.3 & $\begin{array}{l}\text { Forestry } \\
\text { development }\end{array}$ & 28.7 & 3.5 & Forestry development & 151.0 & 9.9 \\
\hline Flood prevention or control & 33.0 & 4.1 & Biosphere protection & 23.2 & 2.9 & Biosphere protection & 93.5 & 6.1 \\
\hline Site preservation & 14.6 & 1.8 & Site preservation & 11.6 & 1.4 & Environmental research & 68.0 & 4.5 \\
\hline Forestry Service & 0.2 & 0.0 & Fuelwood or charcoal & 6.5 & 0.8 & $\begin{array}{l}\text { Environmental education } \\
\text { or training }\end{array}$ & 1.0 & 0.1 \\
\hline $\begin{array}{l}\text { Environmental education or } \\
\text { training }\end{array}$ & 0.0 & 0.0 & $\begin{array}{l}\text { Environmental } \\
\text { education or training }\end{array}$ & 0.3 & 0.0 & Site preservation & 0.6 & 0.0 \\
\hline Forestry research & 0.0 & 0.0 & Forestry research & 0.0 & 0.0 & Forestry research & 0.0 & 0.0 \\
\hline Fuelwood or charcoal & 0.0 & 0.0 & Forestry Service & 0.0 & 0.0 & Forestry Service & 0.0 & 0.0 \\
\hline Forestry education or training & 0.0 & 0.0 & $\begin{array}{l}\text { Forest education or } \\
\text { training }\end{array}$ & 0.0 & 0.0 & Fuelwood or charcoal & 0.0 & 0.0 \\
\hline Environmental research & 0.0 & 0.0 & $\begin{array}{l}\text { Environmental } \\
\text { research }\end{array}$ & 0.0 & 0.0 & $\begin{array}{l}\text { Forestry education or } \\
\text { training }\end{array}$ & 0.0 & 0.0 \\
\hline Total & 806.2 & 100 & Total & 811.8 & 100 & Total & 1520.5 & 100 \\
\hline
\end{tabular}


Table 10. Total FEODA funding areas by topical zone

\begin{tabular}{|c|c|c|c|c|c|c|c|c|}
\hline CA & Total 2008-17 & Share, \% & Amazon Basin & Total 2008-17 & Share, \% & Southeast Asia & Total 2008-17 & Share, \% \\
\hline Biodiversity & 449.0 & 26.5 & $\begin{array}{l}\text { Environmental policy } \\
\text { and administrative } \\
\text { management }\end{array}$ & 2799.4 & 55.3 & $\begin{array}{l}\text { Environmental policy } \\
\text { and administrative } \\
\text { management }\end{array}$ & 4296.0 & 53.2 \\
\hline $\begin{array}{l}\text { Environmental policy and } \\
\text { administrative management }\end{array}$ & 446.4 & 26.3 & Biodiversity & 1314.3 & 26.0 & $\begin{array}{l}\text { Flood prevention or } \\
\text { control }\end{array}$ & 1326.8 & 16.4 \\
\hline $\begin{array}{l}\text { Forestry policy and } \\
\text { administrative management }\end{array}$ & 249.4 & 14.7 & $\begin{array}{l}\text { Forestry policy } \\
\text { and administrative } \\
\text { management }\end{array}$ & 271.4 & 5.4 & Biodiversity & 713.1 & 8.8 \\
\hline Environmental research & 184.9 & 10.9 & Biosphere protection & 219.5 & 4.3 & $\begin{array}{l}\text { Forestry policy } \\
\text { and administrative } \\
\text { management }\end{array}$ & 658.5 & 8.2 \\
\hline Biosphere protection & 176.5 & 10.4 & $\begin{array}{l}\text { Flood prevention or } \\
\text { control }\end{array}$ & 125.4 & 2.5 & Biosphere protection & 517.4 & 6.4 \\
\hline Forestry development & 55.4 & 3.3 & $\begin{array}{l}\text { Forest education or } \\
\text { training }\end{array}$ & 96.7 & 1.9 & $\begin{array}{l}\text { Forest education or } \\
\text { training }\end{array}$ & 179.5 & 2.2 \\
\hline Flood prevention or control & 47.1 & 2.8 & $\begin{array}{l}\text { Environmental } \\
\text { research }\end{array}$ & 87.6 & 1.7 & Forestry development & 155.4 & 1.9 \\
\hline Forest education or training & 44.2 & 2.6 & Site preservation & 81.6 & 1.6 & Environmental research & 152.6 & 1.9 \\
\hline Site preservation & 25.4 & 1.5 & Forestry development & 30.1 & 0.6 & $\begin{array}{l}\text { Environmental education } \\
\text { or training }\end{array}$ & 29.9 & 0.4 \\
\hline Fuelwood or charcoal & 8.9 & 0.5 & $\begin{array}{l}\text { Environmental } \\
\text { education or training }\end{array}$ & 21.0 & 0.4 & Site preservation & 25.9 & 0.3 \\
\hline Forestry Service & 4.0 & 0.2 & Forestry Service & 7.2 & 0.1 & Forestry Service & 13.0 & 0.2 \\
\hline $\begin{array}{l}\text { Environmental education or } \\
\text { training }\end{array}$ & 3.5 & 0.2 & Fuelwood or charcoal & 6.5 & 0.1 & Forestry research & 11.3 & 0.1 \\
\hline Forestry research & 1.4 & 0.1 & Forestry research & 1.0 & 0.0 & Fuelwood or charcoal & 0.0 & 0.0 \\
\hline Total & 1696.0 & 100 & Total & 5061.7 & 100 & Total & 8079.6 & 100 \\
\hline
\end{tabular}


and Southeast Asia. Forestry development ranked fifth for the three tropical zones.

Table 10 shows areas that received total FEODA during the period 2008-2017. In CA, the top five areas covered by flows were biodiversity $(27 \%$ of the total FEODA to CA), environmental policy and administrative management (26\%), forestry policy and administrative management $(15 \%)$, environmental research (11\%), and Biosphere protection (10\%).

In the Amazon Basin, the top five areas covered were environmental policy and administrative management $(55 \%$ of the total FEODA to Amazon Basin), biodiversity (26\%), biosphere protection (5\%), forestry policy and administrative management $(4 \%)$, and flood prevention or control $(3 \%)$.

In Southeast Asia, the top five areas covered were environmental policy and administrative management (53\% of the total FEODA to Southeast Asia), Flood prevention or control $(16 \%)$, biodiversity (9\%), forestry policy and administrative management (8\%), and biosphere protection $(6 \%)$.

The sub-sector that received the lowest total FEODA flow in CA was forestry research (USD 1.4 million), equivalent to $0.1 \%$ of total FEODA to CA. In the Amazon Basin, the lowest funding flow was forestry research (USD 1 million). This was also the case in Southeast Asia (USD 11.3 million), equivalent to $0.1 \%$ of total FEODA.

The common areas covered by FEODA flows across the zones are environmental policy and administrative management, biodiversity, forestry policy and administrative management, and biosphere protection. Environmental policy and administrative management ranked first for Amazon Basin and Southeast Asia, and second for CA. Biodiversity ranked first for CA, second for Amazon Basin and third for Southeast Asia. Forestry policy and administrative management ranked third for CA and Amazon Basin, and fourth for Southeast Asia. Biosphere protection ranked fourth for Amazon Basin and fifth for CA and Southeast Asia.

\subsubsection{Bilateral and multilateral donors in the tropical zone}

Table 11 presents bilateral donors in the tropical zones. In CA, Germany was the largest donor (USD 420 million), representing $47 \%$ of the total bilateral ODA to CA. The United States accounted for $20 \%$ with a total value of USD 173 million. France accounted for $9 \%$ with total value of 84 million. Flows from Japan totaled 53 million, accounting for $6 \%$ of the total bilateral ODA to the region. Sweden accounted for about $4 \%$ with a value of 7 million.

In the Amazon Basin, Norway was the biggest donor (32\%) with a total value of USD 1.3 billion. Flows from Germany totaled USD 1.1 billion, representing $26 \%$ of the total bilateral ODA to the region. France accounted for $14 \%$ with a total value of 611 million. The United States accounted for $11 \%$ with a total value of 458 million. Japan accounted for $4 \%$ with a value of 171 million.

In Southeast Asia, Japan was the main donor, representing $42 \%$, a total value of USD 2.8 billion. France came second with a total value of 1.2 billion, representing 19\%. The United States accounted for $12 \%$ with a total value of 767 million. Flows from Germany totaled 592 million, representing $9 \%$. Norway accounted for about $5 \%$ with a total value of 294 million.

Table 12 shows multilateral donors in the tropical zones. In CA, the EU is the largest donor ( $41 \%$ of sub-regional total) with a total assistance value of USD 329 million. GEF is second with a total value of USD 185 million, equivalent to $23 \%$. The World Bank accounted for $19 \%$ with a total value of USD 155 million. The CIF contributed the total value of 60 million, equivalent to $7 \%$. The AfDB contributed 42 million, equivalent to $5 \%$ of sub-regional total.

In the Amazon Basin, flows from GEF totaled USD 541 million, making it the largest donor with a share of $67 \%$ of the total multilateral flows. The EU was second with a total value of USD 122 million, representing $15 \%$. CIF contributed a total value of USD 75 million, representing 9\%. GCF contributed 47 million, representing 
Table 11. Bilateral Donors by Tropical Zone, 2008-17

\begin{tabular}{|c|c|c|c|c|c|c|c|c|}
\hline \multicolumn{3}{|c|}{ CA } & \multicolumn{3}{|c|}{ Amazon Basin } & \multicolumn{3}{|c|}{ Southeast Asia } \\
\hline Donor & Total & Share, \% & Donor & Total & Share, \% & Donor & Total & Share, \% \\
\hline Germany & 419.5 & 47.2 & Norway & 1346.9 & 31.7 & Japan & 2792.0 & 42.4 \\
\hline United States & 173.1 & 19.5 & Germany & 1101.8 & 26.0 & France & 1224.4 & 18.6 \\
\hline France & 83.8 & 9.4 & France & 611.2 & 14.4 & United States & 766.5 & 11.6 \\
\hline Japan & 53.4 & 6.0 & United States & 455.9 & 10.7 & Germany & 591.6 & 9.0 \\
\hline Sweden & 36.6 & 4.1 & Japan & 170.7 & 4.0 & Norway & 294.0 & 4.5 \\
\hline Norway & 34.1 & 3.8 & United Kingdom & 132.3 & 3.1 & Korea & 243.0 & 3.7 \\
\hline Belgium & 31.3 & 3.5 & Switzerland & 107.5 & 2.5 & Denmark & 112.5 & 1.7 \\
\hline Canada & 21.4 & 2.4 & Netherlands & 83.7 & 2.0 & United Kingdom & 84.7 & 1.3 \\
\hline United Kingdom & 17.2 & 1.9 & Spain & 55.8 & 1.3 & Sweden & 78.6 & 1.2 \\
\hline Netherlands & 8.5 & 1.0 & Denmark & 46.1 & 1.1 & Finland & 72.0 & 1.1 \\
\hline Switzerland & 2.8 & 0.3 & Belgium & 31.4 & 0.7 & Belgium & 54.3 & 0.8 \\
\hline Italy & 2.4 & 0.3 & Canada & 26.3 & 0.6 & Switzerland & 46.1 & 0.7 \\
\hline Spain & 2.0 & 0.2 & Sweden & 24.9 & 0.6 & Canada & 35.7 & 0.5 \\
\hline Korea & 1.7 & 0.2 & Finland & 16.1 & 0.4 & Netherlands & 14.6 & 0.2 \\
\hline Australia & 1.2 & 0.1 & Italy & 14.8 & 0.3 & Italy & 12.5 & 0.2 \\
\hline Austria & 0.5 & 0.1 & Korea & 13.7 & 0.3 & Spain & 7.2 & 0.1 \\
\hline Ireland & 0.2 & 0.0 & Australia & 3.1 & 0.1 & Austria & 2.4 & 0.0 \\
\hline Denmark & 0.0 & 0.0 & Austria & 2.2 & 0.1 & Ireland & 0.5 & 0.0 \\
\hline Finland & 0.0 & 0.0 & Ireland & 0.2 & 0.0 & Australia & 150.3 & 2.3 \\
\hline Total & 889.8 & 100 & Total & 4244.7 & 100 & Total & 6582.8 & 100 \\
\hline
\end{tabular}


Table 12. Multilateral donors by tropical zone, 2008-2017

\begin{tabular}{lrrlrrlrr}
\hline CA & Total & Share, $\%$ & $\begin{array}{l}\text { Amazon } \\
\text { Basin }\end{array}$ & Total & Share, $\%$ & $\begin{array}{l}\text { Southeast } \\
\text { Asia }\end{array}$ & Total & Share, \% \\
\hline EU & 328.6 & 40.8 & GEF & 540.9 & 66.6 & World Bank & 884.7 & 58.2 \\
GEF & 185.4 & 23.0 & EU & 122.1 & 15.0 & GEF & 389.2 & 25.6 \\
World Bank & 154.6 & 19.2 & CIF & 75.1 & 9.2 & CIF & 86.6 & 5.7 \\
CIF & 59.9 & 7.4 & GCF & 47.4 & 5.8 & EU & 86.4 & 5.7 \\
AfDB & 41.6 & 5.2 & World Bank & 11.4 & 1.4 & UNDP & 33.0 & 2.2 \\
UNDP & 25.2 & 3.1 & ITTO & 6.9 & 0.9 & GGGl & 16.3 & 1.1 \\
ITTO & 4.6 & 0.6 & GGGl & 4.9 & 0.6 & ITTO & 15.6 & 1.0 \\
NDF & 4.1 & 0.5 & UNDP & 2.6 & 0.3 & NDF & 8.0 & 0.5 \\
GGGl & 1.9 & 0.2 & Adaptation & 0.3 & 0.0 & FAO & 0.8 & 0.1 \\
FAO & 0.4 & 0.1 & FAO & 0.1 & 0.0 & Adaptation & 0.0 & 0.0 \\
Adaptation & 0.0 & 0.0 & AfDB & 0.0 & 0.0 & AfDB & 0.0 & 0.0 \\
Fund & & & & & & & & \\
GCF & 0.0 & 0.0 & NDF & 0.0 & 0.0 & GCF & 0.0 & 0.0 \\
\hline Total & $\mathbf{8 0 6 . 2}$ & $\mathbf{1 0 0}$ & Total & $\mathbf{8 1 1 . 8}$ & $\mathbf{1 0 0}$ & Total & $\mathbf{1 5 2 0 . 5}$ & $\mathbf{1 0 0}$ \\
\hline
\end{tabular}

6\% and the World Bank contributed 11 million, representing (1\%).

In Southeast Asia, the World Bank was the largest donor with a total value of USD 885 million, equivalent to $58 \%$ of the total multilateral ODA to the sub-region. Flows from GEF totaled USD 389 million, equivalent to $26 \%$ of sub-regional total. CIF and the EU contributed the total value of about USD 86 million each, equivalent to $6 \%$ of sub-regional total. The UNDP contributed 33 million, equivalent to $2 \%$ of the sub-regional total.

\subsection{Needs and opportunities for financing forest and environment in Central Africa}

\subsubsection{Needs for financing forest and environment in Central Africa}

The Congo Basin forests, the second largest tropical forest ecosystem after the Amazon forests, provide numerous benefits and services. They are a storehouse of carbon and biodiversity. They provide livelihoods to 60 million people living in and around them. They also provide social and cultural functions to local and indigenous populations. Importantly, they help to regulate the continental and world climate system. ${ }^{5}$ Global initiatives to curb climate change have recognized their pivotal role, and called for their sustainable management and utilization. However, forest use is not currently sustainable. Of the total tree cover (296 Mha) recorded in the region in 2010 (Table 12), the total tree cover loss from 2001-2017 in CA was about $15 \mathrm{Mha}$, equivalent to $1.7 \mathrm{Gt} \mathrm{CO}_{2}$ emissions. Tree cover gain during 2001-2012 was about $11 \%$ of total tree cover loss, resulting into a net tree cover loss of 13.4 Mha. The total emissions from biomass loss during the period 2001-2017 was 31.6 Gt $\mathrm{CO}_{2}$. Deforestation and forest degradation and the corresponding $\mathrm{CO}_{2}$ emissions pose challenges to the global effort to fight climate change.

\subsubsection{Opportunities for financing forest and environment in Central Africa}

For over two decades, the global community has recognized the need to mobilize funds in

\footnotetext{
5 Baptiste M., Mosnier A., Bodin B., Dessard H., Feintrenie L., Molto Q., Gond V., Bayol N., Batti A., Atyi R.E et Chevalier J.F. 2015. Importance des forêts d'Afrique Centrale. In de Wasseige C, Tadoum M, Eba'a Atyi R and Doumenge C, eds. Les forêts du Bassin du Congo: Forêts et changements climatiques. Neufchâteau, Belgium: Weyrich, pp. 17
} 
Table 13. Selected forestry and environmental statistics of Congo Basin countries

\begin{tabular}{|c|c|c|c|c|c|c|c|c|c|c|}
\hline Country & $\begin{array}{l}\text { Tree cover } \\
\text { in Mha, } \\
2010\end{array}$ & Share, \% & $\begin{array}{l}\text { Tree cover } \\
\text { loss in Kha, } \\
2001-17\end{array}$ & Share, \% & $\begin{array}{l}\text { Equivalent } \mathrm{Co} 2 \\
\text { emissions in } \mathrm{Mt} \\
\text { of } \mathrm{CO}_{2}\end{array}$ & Share, \% & $\begin{array}{l}\text { Tree cover } \\
\text { gain in } \\
\text { Kha, 2001- } \\
12\end{array}$ & Share, \% & $\begin{array}{l}\text { Emission from } \\
\text { biomass loss } \\
\text { in } \mathrm{Mt} \text { of } \mathrm{CO}_{2} \\
2001-17\end{array}$ & Share, \% \\
\hline DRC & 161.00 & 59.83 & 12000.00 & 80.17 & 1330.00 & 79.29 & 1390.00 & 86.28 & 25500.00 & 80.62 \\
\hline CAR & 38.30 & 14.23 & 698.00 & 4.66 & 65.00 & 3.88 & 39.30 & 2.44 & 1550.00 & 4.90 \\
\hline Cameroon & 24.70 & 9.18 & 1080.00 & 7.22 & 137.00 & 8.17 & 65.10 & 4.04 & 2920.00 & 9.23 \\
\hline Congo & 21.60 & 8.03 & 650.00 & 4.34 & 74.30 & 4.43 & 46.70 & 2.90 & 827.00 & 2.61 \\
\hline Gabon & 20.00 & 7.43 & 381.00 & 2.55 & 53.80 & 3.21 & 39.10 & 2.43 & 729.00 & 2.30 \\
\hline Equatorial Guinea & 2.13 & 0.79 & 100.00 & 0.67 & 13.30 & 0.79 & 5.56 & 0.35 & 44.20 & 0.14 \\
\hline Chad & 0.50 & 0.19 & 34.50 & 0.23 & 1.91 & 0.11 & 0.08 & 0.00 & 47.30 & 0.15 \\
\hline Burundi & 0.45 & 0.17 & 22.40 & 0.15 & 1.83 & 0.11 & 3.56 & 0.22 & 5.02 & 0.02 \\
\hline Rwanda & 0.42 & 0.16 & 2.73 & 0.02 & 0.23 & 0.01 & 7.08 & 0.44 & 7.25 & 0.02 \\
\hline $\begin{array}{l}\text { Sao Tome and } \\
\text { Principe }\end{array}$ & 0.01 & 0.00 & 0.08 & 0.00 & 0.01 & 0.00 & 14.50 & 0.90 & 0.04 & 0.00 \\
\hline Total & 269.11 & 100 & 14968.71 & 100 & 1677.37 & 100 & 1610.98 & 100 & 31629.81 & 100 \\
\hline
\end{tabular}

Source: www.globalforestwatch.org

a Hansen, M. C., P. V. Potapov, R. Moore, M. Hancher, S. A. Turubanova, A. Tyukavina, D. Thau, S. V. Stehman, S. J. Goetz, T. R. Loveland, A. Kommareddy, A. Egorov, L. Chini, C. O. Justice, and J. R. G. Townshend. 2013. "High-Resolution Global Maps of 21st-Century Forest Cover Change." Science342 (15 November): 850-53. Data available on-line from:http://earthenginepartners. appspot.com/science-2013-global-forest. Accessed through Global Forest Watch on [12/06/2019]. www.globalforestwatch.org

b Zarin, D., Harris, N.L. et al. 2016. Can carbon emissions drop by 50\% in five years? Global Change Biology, 22: 1336-1347. doi:10.1111/gcb.13153. Accessed through Global Forest Watch on [12/06/2019]. www.globalforestwatch.org 
Table 14. Funding initiatives to support forest and environment

\begin{tabular}{|c|c|c|c|c|c|c|c|c|c|c|c|c|}
\hline Recipient & $\begin{array}{c}\text { UN- } \\
\text { REDD } \\
\text { Program } \\
\text { Partners }\end{array}$ & FCPF & $\mathrm{CIF}$ & GEF & $\begin{array}{c}\text { ITTO } \\
\text { REDDES }\end{array}$ & CBFF & $\begin{array}{l}\text { Adaptation } \\
\text { Fund }\end{array}$ & GCCA & GCF & LDCF & $\begin{array}{c}\text { Special } \\
\text { Climate } \\
\text { Change } \\
\text { Fund } \\
\text { (SCCF) }\end{array}$ & CAFI \\
\hline Burundi & & & & Yes & & & Yes & & & Yes & & \\
\hline Cameroon & Yes & Yes & Yes & Yes & Yes & Yes & & & & & Yes & Yes \\
\hline CAR & Yes & Yes & & Yes & & & & Yes & & Yes & & Yes \\
\hline Chad & Yes & & & Yes & & & Yes & Yes & & Yes & & \\
\hline Congo & Yes & Yes & Yes & Yes & & Yes & & & & & & Yes \\
\hline DRC & Yes & Yes & Yes & Yes & Yes & Yes & & Yes & Yes & Yes & & Yes \\
\hline $\begin{array}{l}\text { Equatorial } \\
\text { Guinea }\end{array}$ & Yes & Yes & & Yes & & Yes & & & & Yes & & Yes \\
\hline Gabon & Yes & Yes & & Yes & Yes & & & & & & & Yes \\
\hline Rwanda & & & Yes & Yes & & & Yes & Yes & Yes & Yes & & \\
\hline $\begin{array}{l}\text { Sao Tome } \\
\text { and Principe }\end{array}$ & & & & Yes & & & & Yes & & Yes & & \\
\hline $\begin{array}{l}\text { Number of } \\
\text { Participants }\end{array}$ & 7 & 6 & 4 & 10 & 3 & 4 & 3 & 5 & 2 & 7 & 1 & 6 \\
\hline
\end{tabular}

Source: Various funding initiatives website (UN-REDD Program Partners, FCPF, CIF, GEF, ITTO REDDES, CBFF, Adaptation Fund, GCCA, GCF, LDCF, SCCF, CAFI)

support of sustainable forest management and fight against climate change. Several funding initiatives have been established as a result. ${ }^{6}, 7,8,9$ These provide opportunities for financing forest and environment programs in CA. Table 14 shows the countries participating in these initiatives. This table is an extension and update from Maniatis (2012). ${ }^{10}$ Since Maniatis's study, the number of Congo Basin countries participating in the United

6 Simula M. 2008. Financing flows and needs to implement the non-legally binding instrument on all types of forests. Prepared for The Advisory Group on Finance of The Collaborative Partnership on Forests.

7 Breanna L et al. 2018. Mapping Forest Finance :A Landscape of Available Sources of Finance for REDD+ and Climate Action in Forests.

8 Asare RA and Gohil D. 2016. The Evolution of Forest Finance in Five African Countries Lessons Learned from the REDDX Initiative in Africa.

9 Advisory Group on Finance. 2012. Collaborative Partnership on Forests, 2012: Study on forest financing.

10 Maniatis D. 2012. Overview of REDD+ in the Congo Basin. Presentation. Climate Change, Deforestation and the Future of African Rainforest, Int'l Conference, 4-6 Jan. 2012, Oxford, UK
Nations Programme on Reducing Emissions from Deforestation and Forest Degradation (UN-REDD), Forest Carbon Partnership Facility (FCPF), GEF and others has increased. All Congo Basin countries are participating in GEF. Seven countries are now partners in UN-REDD. Six are FCPF partners and Central African Forest Initiative (CAFI) partners. The existence of these funding initiatives indicates the readiness and willingness of donors to support efforts to manage forests and the environment sustainably in the Congo Basin. Thus, these are opportunities for Congo Basin countries to finance their forestry and environmental programs.

Over 2008-2017, Congo Basin forests received the least funding (USD 1.7 million) of the tropical zones through bilateral and multilateral sources, compared with the Amazon Basin (USD 5.1 million) and Southeast Asia (USD 8.1 million). This highlights an opportunity for donors to increase funding in the region.

The common areas covered by FEODA flows are environmental policy and administrative 
management, biodiversity, forestry policy and administrative management, and biosphere protection. Environmental policy and administrative management ranked first for Amazon Basin and Southeast Asia, and second for CA. CA's share of the total value committed for environmental policy and administrative management in the three zones (USD 7.5 billion) is 6\%. The Amazon Basin received 37\% and Southeast Asia received 57\%. ODA flow for environmental policy and administrative management could be increased in CA. 


\section{Conclusions}

\subsection{Strengthening external financing of forest and environmental sectors in Central Africa}

The external financing of forest and environmental sectors in CA could be strengthened by: (a) capacity building of Congo Basin countries to access various funding initiatives; (b) engagement with funding initiatives; (c) development of national financing strategies for the forest and environmental sectors; (d) tapping into opportunities for financing forest and environment in CA; and (e) understanding donor policy and objectives for ODA.

\subsubsection{Capacity building of Congo Basin countries}

There are specific requirements to access ODA funds. An applicant country must have the capacity to meet these. OFAC, CAFI and Congo Basin Forest Partnership (CBFP) could facilitate this. OFAC could provide background information and share lessons learned in other Congo Basin countries. CAFI could provide checklists of funding initiative requirements and review funding proposals.

\subsubsection{Engagement with funding initiatives}

Congo Basin countries should engage with the various funding indicatives, especially FCPF, GCF, ITTO - REDDES (Reducing deforestation and forest degradation and enhancing environmental services), Global Climate Change Alliance (GCCA) and CAFI because Central Africa is already in their zone of intervention. Six Congo Basin countries are already partnering with FCPF. These countries should implement their readiness activities quickly in order to access climate funds. At present, GCF has two partners: DRC and Rwanda. Other Congo Basin countries could tap into this fund. Five Congo Basin countries (DRC, Cameroon, Congo, CAR and Gabon) are members of ITTO, but only three countries had REDDES projects during the study period. GCCA currently includes five Congo Basin countries. Other countries can tap into this fund. CAFI is focusing on high forest cover countries in the Congo Basin. Thus, Burundi, Chad, Rwanda and Sao Tome and Principe are not CAFI partners. However, CAFI can help these countries to tap into relevant funding initiatives.

\subsubsection{Development of national financing strategies for forest and environment}

Congo Basin countries should establish a national climate fund that can provide domestic finance for the forest and environmental sectors. This fund can be fed by taxing sales of timber, wood energy, ecotourism and hunting. The strategy should focus on creating enabling conditions for private and international non-governmental organization (NGO) investment into the forest and environmental sectors of CA. It should also specify revenue-generation activities to feed the national climate fund and finance the management of these activities.

\subsubsection{Tapping into opportunities for financing forests and the environment in Central Africa}

The Congo Basin forests are poorly funded and would benefit from increased support from donors. Various funding initiatives for forest and environment provide opportunities for financing forest and environmental sectors in CA. 


\subsubsection{Understanding donor policy and objectives for ODA}

The imbalances and gaps observed in the international funding of forest and environmental sectors in CA result from a misalignment with the policy objectives of donors. Applicant countries that meet the objectives get more and regular funding. Thus, there is a need to review donor policy to identify and develop programs that could attract support. The complete absence of Denmark and Finland in CA should be investigated.

The Congo Basin supports the second largest rainforest in the world, after the Amazon. It offers numerous benefits and services to the local, national and global community. Thus, the forest constitutes a common good of humanity. However, the current use of the forest is unsustainable, with deforestation and forest degradation. Global attention is focused on sustainable management and utilization to ensure that forests are preserved for all stakeholders. Sustainable forest management of involves enormous costs. Thus, there is a need for external financing of forest and environment in the CA.

The global community has recognized the need to mobilize funds in support of sustainable forest management and the fight against climate change. As a result several funding initiatives have been established. These provide opportunities to finance forest and environmental sectors in CA. During 2008-2017, Congo Basin forests received less funding than the Amazon Basin and Southeast Asia. There is a need to increase funding from donors for the region.
In this paper, we provided data on ODA to CA over 2008-2017. The top bilateral donor was Germany, and the top multilateral donor was the EU. The main area covered by bilateral FEODA was biodiversity and by multilateral FEODA was environmental policy and administrative management. The main area covered by total FEODA was biodiversity. The DRC was the main bilateral and multilateral FEODA recipient during the study period. High forest cover countries in the Congo Basin have higher donor presence than low forest cover countries such as Burundi, Chad, Rwanda and Sao Tome and Principe.

In comparison with other tropical zones, the Congo Basin forests were poorly funded during the study period. The top area covered by bilateral FEODA in CA was biodiversity. In the Amazon Basin and Southeast Asia, this was environmental policy and administrative management. The top area covered by multilateral FEODA in CA and Southeast Asia was environmental policy and administrative management. In Amazon Basin, it was biodiversity.

The common areas covered by total FEODA were environmental policy and administrative management, biodiversity, forestry policy and administrative management, and biosphere protection. . Environmental policy and administrative management ranked first for Amazon Basin and Southeast Asia, and second for CA. The CA's share of the total value committed for environmental policy and administrative management in the three zones is the lowest. There is an opportunity to increase ODA flow for environmental policy and administrative management in CA. 


\title{
Appendices
}

\section{Appendix 1. Terms of Reference}

\section{Center for International Forestry Research (CIFOR)}

\author{
Terms of Reference \\ (Consultancy Assignment)
}

$\begin{array}{ll}\text { Title of Assignment: } & \begin{array}{l}\text { Mapping of international funding flows to support the forest and } \\ \text { environment sector in Central Africa }\end{array} \\ \text { Project: } & \text { RIOFAC } \\ \text { Team: } & \text { Forests and Management Restoration (FMR) } \\ \text { Reporting To: } & \text { Richard Eba'a Atyi } \\ \text { Work Location: } & \text { LIBERIA (desk study) }\end{array}$

\section{Background}

CIFOR leads a consortium of technical and scientific institutions in the implementation of the RIOFAC project. The RIOFAC project is funded by the European Union and is designed to provide support to the OFAC.

The geographical scope of the RIOFAC project extends to all member countries of the Commission for the Forests of Central Africa (COMIFAC), including: Cameroon, Central African Republic (CAR), Democratic Republic of Congo (DRC), Republic of Congo, Equatorial Guinea, Gabon, Chad, Burundi, Rwanda and Sao Tome and Principe.

The general objective of the project states that "Up-to-date and relevant information on Central African forests provide private sector, civil society actors and governments the means to make informed decisions from which to build a green economy for endogenous, sustainable and inclusive economic development, while participating in the fight against climate change and in biodiversity conservation".

One of the project outputs is the drafting and publication of a minimum of four policy analysis papers on priority/emerging themes with the involvement of both sub-regional and international expertise in connection with COMIFAC thematic groups. During the regional workshop held in Brazzaville in February 2018, representatives of COMIFAC member countries selected a list of topics to be addressed in policy analysis papers. One of the topics relates to the financing of the forestry and environmental sector of 
Central Africa, especially funds received from international sources for the last decade, to be published in June 2019.

The present study will address the topic of international funding flows targeted to Central Africa in support of the forestry and environment sector. It will serve as a background paper for the policy brief planned for publication by the end of June 2019.

\section{Objectives of the assignment}

The objective of the current assignment is to provide a mapping of international funding flows to support the forest and environment sector in Central Africa, which will serve as a background paper for the OFAC

\section{Scope of the assignment}

The consultant will produce a report as main author with the Supervisor (Richard Eba'a Atyi) as a coauthor. The report will:

- Present and analyse financing flows from 2010 to date directed toward Central Africa in support of nature conservation, sustainable forest management and climate change. The analysis will include both multilateral and the main bilateral sources (EU, Germany, France, Norway, ...)

- Present the main areas (or domains) covered by the current financing flows and identify possible imbalances and gaps

- Provide a comparative analysis between financing flows to Central Africa, and those oriented toward Tropical America (Amazon Basin) and Tropical Asia (South East Asian)

- Identify the needs and opportunities for financing the forest and environment sector of Central Africa

\section{Duration and phasing}

The study will be conducted between February 11, 2019 and April 26, 2019. The main phases include:

- Submission of a study plan including a methodology 15 days after signature of the contract

- Submission of the first draft of the study report 60 days after signature of the contract

- Submission of final draft by April 26, 2019.

\section{Consultant's specification}

- $\mathrm{PhD}$ in environmental Economics or other related fields

- Show a track record of published papers and reports in the field of forestry and environment

- Capacity to work in English or French

- Be familiar with the international financial architecture

- Have a good knowledge of the African context 


\section{Reporting requirements}

The consultant will produce the first draft of the report by the end of March 2019 and the final report two weeks later. The report will be no longer that 60 pages including references. The reports should include tables, graphs and figures for illustration.

Author:

Richard Eba'a Atyi

Date written:

January 2019

\begin{tabular}{|l|l|l|}
\hline Approved by: & Manuel Guariguata & Date approved: 11 February 2019 \\
\hline Reviewed by: & My Devi Musdi & Date reviewed: 06 February 2019 \\
\hline
\end{tabular}


Appendix 2. Breakdown of FEODA (USD million)

\begin{tabular}{|c|c|c|c|c|c|c|c|c|c|c|c|c|}
\hline Flow Type & 2008 & 2009 & 2010 & 2011 & 2012 & 2013 & 2014 & 2015 & 2016 & 2017 & Total & $\begin{array}{c}\text { Share, } \\
\%\end{array}$ \\
\hline \multicolumn{13}{|l|}{ CA FODA } \\
\hline Bilateral & 13.5 & 11.0 & 36.1 & 11.2 & 9.4 & 12.3 & 9.1 & 13.1 & 15.3 & 37.6 & 168.5 & 9.9 \\
\hline Multilateral & 9.2 & 40.1 & 6.6 & 24.3 & 14.9 & 24.8 & 33.8 & 6.2 & 16.8 & 17.9 & 194.7 & 11.5 \\
\hline Total Flow & 22.7 & 51.1 & 42.7 & 35.5 & 24.3 & 37.1 & 42.9 & 19.3 & 32.1 & 55.5 & 363.3 & 21.4 \\
\hline \multicolumn{13}{|l|}{ CA EODA } \\
\hline Bilateral & 53.3 & 44.2 & 41.4 & 55.9 & 71.6 & 159.3 & 44.0 & 117.4 & 112.7 & 21.6 & 721.2 & 42.5 \\
\hline Multilateral & 75.0 & 38.0 & 17.9 & 58.3 & 40.3 & 66.4 & 19.3 & 177.7 & 95.0 & 23.7 & 611.5 & 36.1 \\
\hline Total Flow & 128.3 & 82.1 & 59.2 & 114.2 & 111.8 & 225.7 & 63.3 & 295.1 & 207.7 & 45.3 & 1332.7 & 78.6 \\
\hline \multicolumn{13}{|l|}{ CA FEODA } \\
\hline Bilateral & 66.8 & 55.2 & 77.5 & 67.1 & 81.0 & 171.5 & 53.0 & 130.5 & 128.0 & 59.2 & 889.8 & 52.5 \\
\hline Multilateral & 84.2 & 78.1 & 24.4 & 82.6 & 55.2 & 91.2 & 53.1 & 183.9 & 111.8 & 41.7 & 806.2 & 47.5 \\
\hline Total FEODA & 151.0 & 133.2 & 101.9 & 149.7 & 136.1 & 262.7 & 106.2 & 314.5 & 239.8 & 100.8 & 1696.0 & 100 \\
\hline \multicolumn{13}{|c|}{ Amazon Basin FODA } \\
\hline Bilateral & 7.6 & 40.1 & 43.1 & 54.4 & 4.3 & 3.0 & 2.3 & 51.7 & 46.0 & 15.9 & 268.5 & 5.3 \\
\hline Multilateral & 0.9 & 7.4 & 2.4 & 1.7 & 15.2 & 36.8 & 7.9 & 15.9 & 0.8 & 50.2 & 139.2 & 2.8 \\
\hline Total Flow & 8.5 & 47.5 & 45.5 & 56.1 & 19.5 & 39.9 & 10.2 & 67.6 & 46.8 & 66.1 & 407.7 & 8.1 \\
\hline \multicolumn{13}{|c|}{ Amazon Basin EODA } \\
\hline Bilateral & 143.5 & 233.8 & 531.2 & 361.4 & 383.3 & 324.2 & 391.2 & 725.2 & 465.7 & 416.6 & 3976.1 & 78.6 \\
\hline Multilateral & 36.9 & 72.5 & 43.2 & 35.6 & 119.9 & 55.4 & 35.2 & 60.0 & 143.9 & 70.1 & 672.6 & 13.3 \\
\hline Total Flow & 180.4 & 306.3 & 574.3 & 397.0 & 503.3 & 379.6 & 426.4 & 785.1 & 609.5 & 486.7 & 4648.7 & 91.9 \\
\hline \multicolumn{13}{|c|}{ Amazon Basin FEODA } \\
\hline Bilateral & 151.1 & 273.9 & 574.3 & 415.8 & 387.7 & 327.2 & 393.6 & 776.9 & 511.7 & 432.6 & 4244.7 & 83.9 \\
\hline Multilateral & 37.8 & 79.9 & 45.5 & 37.3 & 135.1 & 92.2 & 43.1 & 75.9 & 144.7 & 120.3 & 811.8 & 16.1 \\
\hline Total FEODA & 188.9 & 353.8 & 619.8 & 453.1 & 522.8 & 419.5 & 436.6 & 852.7 & 656.3 & 552.8 & 5056.5 & 100 \\
\hline \multicolumn{13}{|c|}{ Total Southeast Asia FODA } \\
\hline Bilateral & 59.2 & 42.4 & 47.6 & 68.3 & 234.0 & 64.5 & 110.4 & 14.9 & 35.2 & 31.8 & 708.5 & 8.7 \\
\hline Multilateral & 21.3 & 2.6 & 8.1 & 2.9 & 43.6 & 45.9 & 11.7 & 17.8 & 91.5 & 88.7 & 334.0 & 4.1 \\
\hline Total Flow & 80.4 & 45.1 & 55.7 & 71.2 & 277.6 & 110.5 & 122.2 & 32.7 & 126.7 & 120.5 & 1042.5 & 12.9 \\
\hline \multicolumn{13}{|c|}{ Total Southeast Asia EODA } \\
\hline Bilateral & 599.1 & 739.2 & 1006.4 & 452.9 & 567.5 & 511.8 & 445.5 & 535.8 & 555.7 & 460.4 & 5874.3 & 72.5 \\
\hline Multilateral & 26.6 & 85.2 & 32.0 & 87.6 & 160.1 & 70.5 & 89.3 & 51.4 & 342.6 & 241.3 & 1186.5 & 14.6 \\
\hline Total Flow & 625.7 & 824.4 & 1038.4 & 540.6 & 727.6 & 582.2 & 534.8 & 587.1 & 898.3 & 701.7 & 7060.9 & 87.1 \\
\hline \multicolumn{13}{|c|}{ Southeast Asia FEODA } \\
\hline Bilateral & 658.2 & 781.6 & 1054.0 & 521.2 & 801.6 & 576.3 & 556.0 & 550.6 & 591.0 & 492.3 & 6582.8 & 81.2 \\
\hline Multilateral & 47.9 & 87.9 & 40.1 & 90.5 & 203.6 & 116.4 & 101.0 & 69.2 & 434.1 & 329.9 & 1520.5 & 18.8 \\
\hline Total FEODA & 706.2 & 869.5 & 1094.1 & 611.8 & 1005.2 & 692.7 & 657.0 & 619.8 & 1025.0 & 822.2 & 8103.4 & 100 \\
\hline
\end{tabular}


Appendix 3. Share by donor of total FEODA (USD million)

\begin{tabular}{|c|c|c|c|c|c|c|c|c|c|c|c|c|}
\hline Donor & 2008 & 2009 & 2010 & 2011 & 2012 & 2013 & 2014 & 2015 & 2016 & 2017 & Total & $\begin{array}{c}\text { Share, } \\
\%\end{array}$ \\
\hline Germany & 23.7 & 14.2 & 3.0 & 35.4 & 42.7 & 132.4 & 11.4 & 78.0 & 39.7 & 39.0 & 419.5 & 24.7 \\
\hline EU & 0.0 & 63.6 & 4.8 & 12.2 & 30.0 & 10.4 & 16.3 & 4.5 & 133.7 & 53.1 & 328.6 & 19.4 \\
\hline GEF & 1.0 & 20.4 & 6.7 & 2.4 & 28.5 & 50.4 & 13.3 & 6.0 & 24.1 & 32.6 & 185.4 & 10.9 \\
\hline United States & 22.8 & 20.8 & 10.6 & 9.4 & 10.9 & 14.1 & 15.1 & 21.3 & 40.3 & 7.8 & 173.1 & 10.2 \\
\hline World Bank & 18.4 & 48.4 & 1.0 & 34.5 & 12.2 & 0.0 & 0.0 & 11.2 & 25.4 & 3.5 & 154.6 & 9.1 \\
\hline France & 8.4 & 1.5 & 8.4 & 4.3 & 14.2 & 1.2 & 1.6 & 15.3 & 26.2 & 2.7 & 83.8 & 4.9 \\
\hline CIF & 0.0 & 0.0 & 0.0 & 0.0 & 0.0 & 20.1 & 33.8 & 6.0 & 0.0 & 0.0 & 59.9 & 3.5 \\
\hline Japan & 0.1 & 0.9 & 31.5 & 0.8 & 1.7 & 4.0 & 4.0 & 4.2 & 5.3 & 1.1 & 53.4 & 3.1 \\
\hline AfDB & 0.0 & 0.0 & 0.0 & 13.4 & 0.0 & 0.3 & 0.0 & 24.9 & 1.7 & 1.3 & 41.6 & 2.5 \\
\hline Sweden & 0.0 & 0.0 & 8.3 & 8.9 & 0.1 & 1.6 & 7.9 & 2.3 & 7.4 & 0.1 & 36.6 & 2.2 \\
\hline Norway & 1.8 & 0.4 & 1.7 & 0.0 & 4.3 & 3.9 & 8.1 & 2.2 & 7.5 & 4.3 & 34.1 & 2.0 \\
\hline Belgium & 1.3 & 6.2 & 10.6 & 0.8 & 4.8 & 0.8 & 0.0 & 3.9 & 0.6 & 2.2 & 31.3 & 1.8 \\
\hline UNDP & 1.3 & 2.6 & 2.4 & 2.1 & 3.8 & 3.6 & 1.5 & 1.9 & 3.2 & 2.6 & 25.2 & 1.5 \\
\hline Canada & 4.3 & 8.1 & 0.7 & 5.8 & 1.4 & 0.9 & 0.2 & 0.0 & 0.0 & 0.0 & 21.4 & 1.3 \\
\hline $\begin{array}{l}\text { United } \\
\text { Kingdom }\end{array}$ & 3.3 & 0.7 & 0.4 & 1.2 & 0.1 & 4.6 & 3.7 & 1.2 & 0.8 & 1.2 & 17.2 & 1.0 \\
\hline Netherlands & 0.0 & 0.0 & 0.1 & 0.0 & 0.0 & 6.7 & 0.0 & 1.7 & 0.0 & 0.1 & 8.5 & 0.5 \\
\hline ITTO & 0.0 & 0.0 & 1.8 & 2.1 & 0.2 & 0.2 & 0.0 & 0.0 & 0.2 & 0.0 & 4.6 & 0.3 \\
\hline NDF & 0.0 & 0.0 & 0.0 & 0.0 & 0.0 & 0.0 & 0.0 & 0.0 & 4.1 & 0.0 & 4.1 & 0.2 \\
\hline Switzerland & 0.1 & 1.4 & 1.0 & 0.0 & 0.0 & 0.0 & 0.1 & 0.0 & 0.0 & 0.1 & 2.8 & 0.2 \\
\hline Italy & 0.7 & 0.7 & 0.1 & 0.2 & 0.2 & 0.0 & 0.0 & 0.0 & 0.1 & 0.4 & 2.4 & 0.1 \\
\hline Spain & 0.2 & 0.4 & 1.2 & 0.2 & 0.0 & 0.0 & 0.0 & 0.1 & 0.0 & 0.0 & 2.0 & 0.1 \\
\hline GGGI & 0.0 & 0.0 & 0.0 & 0.0 & 0.0 & 0.0 & 0.0 & 0.0 & 0.3 & 1.6 & 1.9 & 0.1 \\
\hline Korea & 0.0 & 0.0 & 0.1 & 0.1 & 0.7 & 0.2 & 0.3 & 0.1 & 0.1 & 0.1 & 1.7 & 0.1 \\
\hline Australia & 0.0 & 0.0 & 0.0 & 0.0 & 0.0 & 0.4 & 0.5 & 0.3 & 0.0 & 0.0 & 1.2 & 0.1 \\
\hline Austria & 0.0 & 0.0 & 0.0 & 0.0 & 0.0 & 0.5 & 0.0 & 0.0 & 0.0 & 0.0 & 0.5 & 0.0 \\
\hline FAO & 0.0 & 0.0 & 0.0 & 0.0 & 0.0 & 0.4 & 0.0 & 0.0 & 0.0 & 0.0 & 0.4 & 0.0 \\
\hline Ireland & 0.0 & 0.0 & 0.0 & 0.0 & 0.0 & 0.0 & 0.0 & 0.0 & 0.0 & 0.2 & 0.2 & 0.0 \\
\hline Denmark & 0.0 & 0.0 & 0.0 & 0.0 & 0.0 & 0.0 & 0.0 & 0.0 & 0.0 & 0.0 & 0.0 & 0.0 \\
\hline Finland & 0.0 & 0.0 & 0.0 & 0.0 & 0.0 & 0.0 & 0.0 & 0.0 & 0.0 & 0.0 & 0.0 & 0.0 \\
\hline $\begin{array}{l}\text { Adaptation } \\
\text { Fund }\end{array}$ & 0.0 & 0.0 & 0.0 & 0.0 & 0.0 & 0.0 & 0.0 & 0.0 & 0.0 & 0.0 & 0.0 & 0.0 \\
\hline GCF & 0.0 & 0.0 & 0.0 & 0.0 & 0.0 & 0.0 & 0.0 & 0.0 & 0.0 & 0.0 & 0.0 & 0.0 \\
\hline Total & 87.4 & 190.2 & 94.2 & 133.8 & 155.7 & 257.0 & 118.0 & 185.0 & 320.7 & 153.9 & 1696.0 & 100 \\
\hline
\end{tabular}




\section{Appendix 4. Recipients of total FEODA (USD million)}

\begin{tabular}{|c|c|c|c|c|c|c|c|c|c|c|c|c|}
\hline Recipient & 2008 & 2009 & 2010 & 2011 & 2012 & 2013 & 2014 & 2015 & 2016 & 2017 & Total & $\begin{array}{c}\text { Share, } \\
\%\end{array}$ \\
\hline Burundi & 0.6 & 8.3 & 2.8 & 14.9 & 2.8 & 1.2 & 0.9 & 11.6 & 0.9 & 1.5 & 45.6 & 0.3 \\
\hline Cameroon & 26.1 & 13.7 & 27.9 & 19.0 & 10.4 & 20.5 & 13.9 & 35.8 & 23.5 & 42.2 & 233.0 & 1.6 \\
\hline CAR & 18.6 & 23.1 & 1.3 & 9.1 & 4.9 & 1.4 & 0.4 & 7.3 & 8.5 & 0.1 & 74.8 & 0.5 \\
\hline Chad & 16.9 & 10.6 & 2.2 & 18.3 & 4.2 & 98.9 & 2.9 & 69.6 & 69.2 & 2.7 & 295.6 & 2.0 \\
\hline Congo & 9.6 & 5.4 & 2.2 & 7.9 & 19.9 & 2.0 & 4.5 & 1.4 & 3.9 & 13.3 & 70.1 & 0.5 \\
\hline DRC & 74.6 & 59.1 & 33.9 & 50.0 & 57.6 & 94.2 & 59.5 & 164.5 & 62.6 & 25.8 & 681.8 & 4.6 \\
\hline $\begin{array}{l}\text { Equatorial } \\
\text { Guinea }\end{array}$ & 0.1 & 1.0 & 0.3 & 1.0 & 0.3 & 0.2 & 0.1 & 0.3 & 1.5 & 0.0 & 4.8 & 0.0 \\
\hline Gabon & 0.6 & 3.2 & 9.4 & 5.4 & 17.6 & 14.2 & 6.2 & 9.2 & 50.7 & 2.4 & 118.9 & 0.8 \\
\hline Rwanda & 3.7 & 8.1 & 21.8 & 21.9 & 14.6 & 22.9 & 17.9 & 14.7 & 18.9 & 12.6 & 157.1 & 1.1 \\
\hline $\begin{array}{l}\text { Sao Tome } \\
\text { and } \\
\text { Principe }\end{array}$ & 0.1 & 0.7 & 0.0 & 2.2 & 3.9 & 7.1 & 0.0 & 0.0 & 0.1 & 0.2 & 14.3 & 0.1 \\
\hline Sub-Total & 151.0 & 133.2 & 101.9 & 149.7 & 136.1 & 262.7 & 106.2 & 314.5 & 239.8 & 100.8 & 1696.0 & 11.4 \\
\hline Brazil & 79.5 & 114.6 & 282.9 & 294.4 & 261.9 & 177.1 & 151.6 & 221.8 & 235.6 & 204.7 & 2024.0 & 13.6 \\
\hline Bolivia & 24.7 & 79.2 & 29.6 & 23.0 & 32.7 & 48.8 & 25.1 & 21.6 & 7.6 & 5.3 & 297.6 & 2.0 \\
\hline Colombia & 10.0 & 20.8 & 26.6 & 17.8 & 39.5 & 71.3 & 45.7 & 523.5 & 218.2 & 220.8 & 1194.2 & 8.0 \\
\hline Ecuador & 16.5 & 56.3 & 26.1 & 23.1 & 23.7 & 37.8 & 48.7 & 15.2 & 77.1 & 7.5 & 332.0 & 2.2 \\
\hline $\begin{array}{l}\text { French } \\
\text { Guiana }\end{array}$ & 0.1 & 0.0 & 0.0 & 0.4 & 0.0 & 0.0 & 0.1 & 0.1 & 0.0 & 0.0 & 0.7 & 0.0 \\
\hline Guyana & 5.1 & 12.7 & 196.6 & 8.0 & 5.2 & 17.6 & 83.9 & 4.1 & 42.6 & 11.8 & 387.6 & 2.6 \\
\hline Peru & 33.4 & 54.1 & 56.3 & 84.2 & 154.3 & 53.2 & 81.2 & 62.6 & 66.7 & 102.6 & 748.4 & 5.0 \\
\hline Suriname & 18.8 & 0.6 & 1.0 & 1.3 & 4.6 & 1.0 & 0.1 & 3.7 & 8.5 & 0.0 & 39.7 & 0.3 \\
\hline Venezuela & 0.8 & 15.5 & 0.8 & 0.9 & 0.9 & 12.6 & 0.1 & 0.2 & 0.0 & 0.3 & 32.2 & 0.2 \\
\hline Sub-Total & 188.9 & 353.8 & 619.8 & 453.1 & 522.8 & 419.5 & 436.6 & 852.7 & 656.3 & 552.8 & 5056.5 & 34.0 \\
\hline Brunei & 0.0 & 0.0 & 0.0 & 0.0 & 0.0 & 0.0 & 0.0 & 0.0 & 0.0 & 0.0 & 0.0 & 0.0 \\
\hline Cambodia & 5.5 & 10.1 & 34.5 & 52.3 & 41.9 & 18.3 & 40.8 & 18.2 & 99.7 & 33.7 & 355.0 & 2.4 \\
\hline Indonesia & 522.4 & 636.5 & 752.1 & 150.6 & 162.4 & 259.8 & 202.9 & 168.1 & 177.4 & 112.1 & 3144.1 & 21.2 \\
\hline LPDR & 33.0 & 24.2 & 37.8 & 32.6 & 34.8 & 55.2 & 83.1 & 18.9 & 20.2 & 20.8 & 360.4 & 2.4 \\
\hline Malaysia & 1.7 & 7.0 & 19.3 & 3.4 & 18.7 & 6.9 & 3.7 & 6.9 & 13.1 & 6.0 & 86.7 & 0.6 \\
\hline Myanmar & 3.4 & 1.4 & 1.7 & 4.5 & 14.1 & 27.4 & 24.6 & 20.5 & 230.4 & 52.9 & 381.0 & 2.6 \\
\hline Philippines & 26.7 & 49.9 & 41.6 & 42.2 & 341.1 & 17.8 & 44.9 & 151.9 & 88.9 & 190.3 & 995.3 & 6.7 \\
\hline Singapore & 0.0 & 0.0 & 0.0 & 0.0 & 0.0 & 0.0 & 0.0 & 0.0 & 0.0 & 0.0 & 0.0 & 0.0 \\
\hline Thailand & 6.9 & 6.0 & 20.3 & 11.1 & 15.2 & 14.5 & 7.4 & 30.0 & 14.0 & 6.0 & 131.4 & 0.9 \\
\hline $\begin{array}{l}\text { Timor- } \\
\text { Leste }\end{array}$ & 2.3 & 2.1 & 2.8 & 4.5 & 13.1 & 7.7 & 13.7 & 6.0 & 36.5 & 5.0 & 93.7 & 0.6 \\
\hline Viet Nam & 104.4 & 132.3 & 184.0 & 310.6 & 363.9 & 285.3 & 235.9 & 199.3 & 344.9 & 395.4 & 2555.9 & 17.2 \\
\hline Sub-Total & 706.2 & 869.5 & 1094.1 & 611.8 & 1005.2 & 692.7 & 657.0 & 619.8 & 1025.0 & 822.2 & 8103.4 & 54.5 \\
\hline $\begin{array}{l}\text { Grand } \\
\text { Total }\end{array}$ & 1046.0 & 1356.5 & 1815.8 & 1214.6 & 1664.1 & 1374.9 & 1199.8 & 1787.0 & 1921.1 & 1475.9 & 14855.8 & 100 \\
\hline
\end{tabular}




\section{Appendix 5. Recipients of bilateral FEODA (USD million)}

\begin{tabular}{|c|c|c|c|c|c|c|c|c|c|c|c|c|}
\hline Recipient & 2008 & 2009 & 2010 & 2011 & 2012 & 2013 & 2014 & 2015 & 2016 & 2017 & Total & $\begin{array}{c}\text { Share, } \\
\%\end{array}$ \\
\hline Burundi & 0.6 & 1.1 & 2.8 & 0.2 & 0.6 & 0.1 & 0.4 & 0.1 & 0.1 & 0.0 & 6.2 & 0.1 \\
\hline Cameroon & 5.7 & 4.5 & 12.3 & 18.6 & 3.9 & 7.0 & 10.1 & 17.8 & 12.4 & 40.9 & 133.0 & 1.1 \\
\hline CAR & 17.2 & 15.9 & 0.0 & 1.3 & 0.1 & 0.2 & 0.4 & 7.3 & 0.3 & 0.1 & 42.8 & 0.4 \\
\hline Chad & 0.9 & 7.0 & 1.3 & 4.7 & 3.8 & 82.8 & 2.6 & 56.3 & 20.9 & 2.6 & 183.0 & 1.6 \\
\hline Congo & 7.0 & 3.9 & 1.2 & 2.0 & 4.8 & 0.8 & 1.0 & 1.1 & 1.7 & 1.0 & 24.3 & 0.2 \\
\hline DRC & 31.5 & 12.8 & 32.4 & 24.7 & 46.2 & 58.7 & 19.2 & 24.5 & 42.6 & 8.0 & 300.6 & 2.6 \\
\hline $\begin{array}{l}\text { Equatorial } \\
\text { Guinea }\end{array}$ & 0.0 & 0.9 & 0.2 & 1.0 & 0.1 & 0.1 & 0.1 & 0.3 & 1.5 & 0.0 & 4.2 & 0.0 \\
\hline Gabon & 0.6 & 1.7 & 8.1 & 5.2 & 17.4 & 6.3 & 6.2 & 8.8 & 41.5 & 1.0 & 96.8 & 0.8 \\
\hline Rwanda & 3.3 & 6.8 & 19.2 & 9.5 & 4.0 & 15.4 & 13.2 & 14.3 & 6.8 & 5.5 & 97.9 & 0.8 \\
\hline $\begin{array}{l}\text { Sao Tome } \\
\text { and Principe }\end{array}$ & 0.0 & 0.7 & 0.0 & 0.0 & 0.0 & 0.1 & 0.0 & 0.0 & 0.1 & 0.2 & 1.1 & 0.0 \\
\hline Sub-Total & 66.8 & 55.2 & 77.5 & 67.1 & 81.0 & 171.5 & 53.0 & 130.5 & 128.0 & 59.2 & 889.8 & 7.6 \\
\hline Brazil & 50.2 & 98.5 & 249.9 & 273.7 & 201.2 & 146.6 & 140.4 & 204.5 & 207.2 & 161.8 & 1733.9 & 14.8 \\
\hline Bolivia & 24.7 & 66.1 & 29.6 & 16.8 & 11.1 & 46.7 & 19.1 & 21.6 & 3.9 & 5.3 & 245.0 & 2.1 \\
\hline Colombia & 10.0 & 8.7 & 18.9 & 12.9 & 25.6 & 48.7 & 35.7 & 499.9 & 215.6 & 199.0 & 1075.0 & 9.2 \\
\hline Ecuador & 13.4 & 48.0 & 26.1 & 19.2 & 8.4 & 33.1 & 48.7 & 2.4 & 19.6 & 3.3 & 222.1 & 1.9 \\
\hline $\begin{array}{l}\text { French } \\
\text { Guiana }\end{array}$ & 0.1 & 0.0 & 0.0 & 0.4 & 0.0 & 0.0 & 0.1 & 0.1 & 0.0 & 0.0 & 0.7 & 0.0 \\
\hline Guyana & 0.8 & 7.1 & 196.2 & 7.6 & 5.1 & 0.3 & 72.2 & 3.0 & 9.3 & 7.6 & 309.3 & 2.6 \\
\hline Peru & 32.2 & 45.0 & 52.8 & 83.2 & 130.8 & 51.7 & 77.3 & 44.8 & 55.7 & 55.4 & 628.9 & 5.4 \\
\hline Suriname & 18.8 & 0.0 & 0.0 & 1.2 & 4.5 & 0.0 & 0.0 & 0.4 & 0.3 & 0.0 & 25.3 & 0.2 \\
\hline Venezuela & 0.8 & 0.5 & 0.8 & 0.7 & 0.9 & 0.2 & 0.1 & 0.2 & 0.0 & 0.2 & 4.4 & 0.0 \\
\hline Sub-Total & 151.1 & 273.9 & 574.3 & 415.8 & 387.7 & 327.2 & 393.6 & 776.9 & 511.7 & 432.6 & 4244.7 & 36.2 \\
\hline Brunei & 0.0 & 0.0 & 0.0 & 0.0 & 0.0 & 0.0 & 0.0 & 0.0 & 0.0 & 0.0 & 0.0 & 0.0 \\
\hline Cambodia & 4.9 & 6.6 & 33.5 & 50.3 & 28.6 & 14.5 & 31.3 & 13.7 & 98.9 & 32.2 & 314.3 & 2.7 \\
\hline Indonesia & 513.3 & 625.7 & 747.5 & 126.5 & 135.3 & 237.6 & 183.3 & 137.4 & 148.9 & 93.9 & 2949.4 & 25.2 \\
\hline LPDR & 23.8 & 18.3 & 33.5 & 26.2 & 26.8 & 25.8 & 48.5 & 3.6 & 5.8 & 7.1 & 219.6 & 1.9 \\
\hline Malaysia & 1.7 & 1.9 & 3.3 & 2.6 & 2.9 & 3.3 & 2.4 & 5.8 & 3.3 & 5.0 & 32.3 & 0.3 \\
\hline Myanmar & 3.4 & 1.4 & 1.7 & 4.0 & 14.0 & 6.4 & 11.1 & 15.0 & 16.9 & 12.4 & 86.2 & 0.7 \\
\hline Philippines & 21.7 & 35.5 & 37.5 & 37.6 & 333.2 & 15.7 & 42.8 & 144.7 & 86.9 & 173.6 & 929.0 & 7.9 \\
\hline Singapore & 0.0 & 0.0 & 0.0 & 0.0 & 0.0 & 0.0 & 0.0 & 0.0 & 0.0 & 0.0 & 0.0 & 0.0 \\
\hline Thailand & 5.8 & 5.1 & 14.3 & 10.9 & 8.5 & 8.9 & 3.8 & 29.8 & 8.3 & 2.6 & 98.1 & 0.8 \\
\hline Timor-Leste & 2.3 & 2.0 & 2.6 & 4.4 & 7.7 & 2.4 & 1.9 & 2.9 & 1.8 & 3.5 & 31.4 & 0.3 \\
\hline Viet Nam & 81.3 & 85.1 & 180.1 & 258.8 & 244.6 & 261.7 & 231.0 & 197.6 & 220.2 & 162.0 & 1922.5 & 16.4 \\
\hline Sub-Total & 658.2 & 781.6 & 1054.0 & 521.2 & 801.6 & 576.3 & 556.0 & 550.6 & 591.0 & 492.3 & 6582.8 & 56.2 \\
\hline Grand Total & 876.1 & 1110.7 & 1705.8 & 1004.2 & 1270.2 & 1075.1 & 1002.6 & 1458.0 & 1230.6 & 984.0 & 11717.2 & 100 \\
\hline
\end{tabular}


Appendix 6. Recipients of multilateral FEODA (USD million)

\begin{tabular}{|c|c|c|c|c|c|c|c|c|c|c|c|c|}
\hline Recipient & 2008 & 2009 & 2010 & 2011 & 2012 & 2013 & 2014 & 2015 & 2016 & 2017 & Total & $\begin{array}{c}\text { Share, } \\
\%\end{array}$ \\
\hline Burundi & 0.0 & 7.1 & 0.0 & 14.7 & 2.2 & 1.1 & 0.6 & 11.5 & 0.8 & 1.5 & 39.4 & 1.3 \\
\hline Cameroon & 20.4 & 9.3 & 15.7 & 0.4 & 6.5 & 13.5 & 3.8 & 18.1 & 11.1 & 1.3 & 100.0 & 3.2 \\
\hline CAR & 1.4 & 7.2 & 1.3 & 7.9 & 4.8 & 1.2 & 0.0 & 0.0 & 8.2 & 0.0 & 32.0 & 1.0 \\
\hline Chad & 16.0 & 3.6 & 1.0 & 13.5 & 0.3 & 16.1 & 0.2 & 13.3 & 48.3 & 0.1 & 112.5 & 3.6 \\
\hline Congo & 2.7 & 1.6 & 1.1 & 5.9 & 15.0 & 1.2 & 3.5 & 0.3 & 2.1 & 12.3 & 45.8 & 1.5 \\
\hline DRC & 43.2 & 46.3 & 1.5 & 25.3 & 11.3 & 35.5 & 40.3 & 140.0 & 20.0 & 17.8 & 381.2 & 12.1 \\
\hline $\begin{array}{l}\text { Equatorial } \\
\text { Guinea }\end{array}$ & 0.0 & 0.1 & 0.1 & 0.1 & 0.2 & 0.1 & 0.0 & 0.0 & 0.0 & 0.0 & 0.7 & 0.0 \\
\hline Gabon & 0.0 & 1.5 & 1.4 & 0.2 & 0.2 & 7.9 & 0.0 & 0.4 & 9.3 & 1.4 & 22.2 & 0.7 \\
\hline Rwanda & 0.4 & 1.4 & 2.6 & 12.4 & 10.6 & 7.5 & 4.7 & 0.4 & 12.1 & 7.2 & 59.2 & 1.9 \\
\hline $\begin{array}{l}\text { Sao Tome } \\
\text { and Principe }\end{array}$ & 0.0 & 0.0 & 0.0 & 2.2 & 3.9 & 7.1 & 0.0 & 0.0 & 0.0 & 0.0 & 13.2 & 0.4 \\
\hline Sub-Total & 84.2 & 78.1 & 24.4 & 82.6 & 55.2 & 91.2 & 53.1 & 183.9 & 111.8 & 41.7 & 806.2 & 25.7 \\
\hline Brazil & 29.3 & 16.1 & 33.0 & 20.7 & 60.7 & 30.5 & 11.2 & 17.4 & 28.4 & 42.8 & 290.1 & 9.2 \\
\hline Bolivia & 0.0 & 13.0 & 0.0 & 6.2 & 21.6 & 2.1 & 6.1 & 0.0 & 3.6 & 0.0 & 52.7 & 1.7 \\
\hline Colombia & 0.0 & 12.1 & 7.7 & 5.0 & 13.9 & 22.6 & 10.1 & 23.5 & 2.6 & 21.7 & 119.2 & 3.8 \\
\hline Ecuador & 3.0 & 8.3 & 0.0 & 3.9 & 15.3 & 4.7 & 0.1 & 12.7 & 57.5 & 4.3 & 109.9 & 3.5 \\
\hline $\begin{array}{l}\text { French } \\
\text { Guiana }\end{array}$ & 0.0 & 0.0 & 0.0 & 0.0 & 0.0 & 0.0 & 0.0 & 0.0 & 0.0 & 0.0 & 0.0 & 0.0 \\
\hline Guyana & 4.3 & 5.6 & 0.4 & 0.3 & 0.1 & 17.3 & 11.7 & 1.0 & 33.3 & 4.2 & 78.3 & 2.5 \\
\hline Peru & 1.2 & 9.1 & 3.4 & 1.0 & 23.5 & 1.5 & 3.8 & 17.8 & 11.0 & 47.2 & 119.5 & 3.8 \\
\hline Suriname & 0.0 & 0.6 & 1.0 & 0.1 & 0.1 & 1.0 & 0.1 & 3.3 & 8.3 & 0.0 & 14.4 & 0.5 \\
\hline Venezuela & 0.0 & 15.1 & 0.0 & 0.1 & 0.0 & 12.5 & 0.0 & 0.0 & 0.0 & 0.1 & 27.8 & 0.9 \\
\hline Sub-Total & 37.8 & 79.9 & 45.5 & 37.3 & 135.1 & 92.2 & 43.1 & 75.9 & 144.7 & 120.3 & 811.8 & 25.9 \\
\hline Brunei & 0.0 & 0.0 & 0.0 & 0.0 & 0.0 & 0.0 & 0.0 & 0.0 & 0.0 & 0.0 & 0.0 & 0.0 \\
\hline Cambodia & 0.6 & 3.6 & 1.0 & 1.9 & 13.4 & 3.8 & 9.5 & 4.5 & 0.9 & 1.5 & 40.7 & 1.3 \\
\hline Indonesia & 9.0 & 10.7 & 4.6 & 24.1 & 27.1 & 22.2 & 19.6 & 30.7 & 28.5 & 18.2 & 194.7 & 6.2 \\
\hline LPDR & 9.2 & 5.9 & 4.3 & 6.4 & 7.9 & 29.3 & 34.6 & 15.3 & 14.3 & 13.7 & 140.8 & 4.5 \\
\hline Malaysia & 0.0 & 5.1 & 16.1 & 0.8 & 15.8 & 3.6 & 1.4 & 1.0 & 9.8 & 0.9 & 54.4 & 1.7 \\
\hline Myanmar & 0.0 & 0.1 & 0.0 & 0.6 & 0.1 & 21.0 & 13.5 & 5.5 & 213.5 & 40.5 & 294.7 & 9.4 \\
\hline Philippines & 5.0 & 14.4 & 4.1 & 4.6 & 7.9 & 2.2 & 2.2 & 7.2 & 2.0 & 16.7 & 66.2 & 2.1 \\
\hline Singapore & 0.0 & 0.0 & 0.0 & 0.0 & 0.0 & 0.0 & 0.0 & 0.0 & 0.0 & 0.0 & 0.0 & 0.0 \\
\hline Thailand & 1.1 & 0.9 & 6.0 & 0.2 & 6.7 & 5.5 & 3.7 & 0.2 & 5.7 & 3.4 & 33.3 & 1.1 \\
\hline Timor-Leste & 0.0 & 0.1 & 0.2 & 0.1 & 5.4 & 5.3 & 11.7 & 3.1 & 34.8 & 1.6 & 62.2 & 2.0 \\
\hline Viet Nam & 23.1 & 47.1 & 3.9 & 51.8 & 119.3 & 23.6 & 4.9 & 1.7 & 124.7 & 233.4 & 633.4 & 20.2 \\
\hline Sub-Total & 47.9 & 87.9 & 40.1 & 90.5 & 203.6 & 116.4 & 101.0 & 69.2 & 434.1 & 329.9 & 1520.5 & 48.4 \\
\hline Grand Total & 170.0 & 245.8 & 110.1 & 210.4 & 393.9 & 299.8 & 197.2 & 329.0 & 690.5 & 491.8 & 3138.6 & 100 \\
\hline
\end{tabular}


Appendix 7. Total FEODA by area and by tropical zone (USD million)

\begin{tabular}{|c|c|c|c|c|c|c|c|c|c|c|c|c|}
\hline Area & 2008 & 2009 & 2010 & 2011 & 2012 & 2013 & 2014 & 2015 & 2016 & 2017 & Total & Share, \% \\
\hline \multicolumn{13}{|l|}{ CA } \\
\hline Biodiversity & 57.2 & 16.7 & 12.4 & 61.7 & 64.8 & 79.1 & 19.7 & 27.9 & 90.6 & 19.0 & 449.0 & 3.0 \\
\hline Biosphere protection & 0.8 & 0.3 & 1.3 & 9.7 & 10.6 & 5.8 & 2.7 & 139.2 & 1.8 & 4.4 & 176.5 & 1.2 \\
\hline Environmental education or training & 0.3 & 0.6 & 0.3 & 0.2 & 0.4 & 0.7 & 0.5 & 0.1 & 0.3 & 0.2 & 3.5 & 0.0 \\
\hline $\begin{array}{l}\text { Environmental policy and administrative } \\
\text { management }\end{array}$ & 68.8 & 52.6 & 23.7 & 35.9 & 22.1 & 54.6 & 36.6 & 53.3 & 82.1 & 16.6 & 446.4 & 3.0 \\
\hline Environmental research & 0.9 & 5.0 & 2.1 & 5.6 & 4.9 & 82.2 & 3.4 & 62.3 & 13.4 & 5.1 & 184.9 & 1.2 \\
\hline Flood prevention or control & 0.0 & 0.0 & 14.0 & 1.1 & 0.0 & 2.9 & 0.0 & 11.2 & 18.0 & 0.0 & 47.1 & 0.3 \\
\hline Forest education or training & 0.5 & 2.4 & 0.4 & 0.3 & 0.6 & 0.6 & 0.0 & 2.0 & 3.3 & 34.1 & 44.2 & 0.3 \\
\hline Forestry development & 9.3 & 21.9 & 2.3 & 0.2 & 1.6 & 0.2 & 0.1 & 6.4 & 5.8 & 7.5 & 55.4 & 0.4 \\
\hline Forestry policy and administrative management & 12.9 & 26.8 & 40.0 & 31.0 & 21.9 & 28.8 & 42.3 & 9.0 & 23.0 & 13.8 & 249.4 & 1.7 \\
\hline Forestry research & 0.0 & 0.0 & 0.0 & 0.2 & 0.2 & 0.1 & 0.5 & 0.3 & 0.0 & 0.0 & 1.4 & 0.0 \\
\hline Forestry service & 0.0 & 0.0 & 0.0 & 3.8 & 0.0 & 0.0 & 0.2 & 0.0 & 0.0 & 0.0 & 4.0 & 0.0 \\
\hline Fuelwood or charcoal & 0.0 & 0.0 & 0.0 & 0.0 & 0.0 & 7.1 & 0.0 & 1.7 & 0.0 & 0.1 & 8.9 & 0.1 \\
\hline Site preservation & 0.3 & 6.9 & 5.4 & 0.1 & 9.1 & 0.5 & 0.3 & 1.2 & 1.5 & 0.0 & 25.4 & 0.2 \\
\hline Sub-Total & 151.0 & 133.2 & 101.9 & 149.7 & 136.1 & 262.5 & 106.4 & 314.5 & 239.8 & 100.8 & 1696.0 & 11.4 \\
\hline \multicolumn{13}{|l|}{ Amazon Basin } \\
\hline Biodiversity & 49.1 & 91.4 & 97.7 & 150.6 & 160.0 & 97.0 & 104.9 & 205.0 & 97.1 & 261.5 & 1314.3 & 8.9 \\
\hline Biosphere protection & 3.3 & 5.4 & 27.5 & 25.2 & 35.9 & 35.1 & 37.8 & 22.0 & 9.6 & 17.7 & 219.5 & 1.5 \\
\hline Environmental education or training & 1.8 & 3.0 & 1.6 & 1.3 & 1.3 & 3.3 & 2.0 & 3.1 & 0.6 & 3.1 & 21.0 & 0.1 \\
\hline $\begin{array}{l}\text { Environmental policy and administrative } \\
\text { management }\end{array}$ & 94.4 & 193.2 & 429.8 & 197.4 & 273.4 & 222.4 & 244.4 & 520.6 & 448.1 & 175.9 & 2799.4 & 18.9 \\
\hline Environmental research & 2.6 & 4.2 & 8.0 & 11.8 & 10.6 & 4.4 & 1.7 & 7.8 & 18.0 & 18.6 & 87.6 & 0.6 \\
\hline Flood prevention or control & 19.9 & 5.2 & 5.4 & 9.3 & 1.1 & 16.9 & 34.1 & 0.0 & 33.4 & 0.1 & 125.4 & 0.8 \\
\hline Forest education or training & 1.4 & 26.1 & 6.5 & 3.1 & 1.2 & 1.0 & 0.4 & 3.3 & 42.0 & 11.8 & 96.7 & 0.7 \\
\hline Forestry development & 0.9 & 2.1 & 0.8 & 1.6 & 0.3 & 0.8 & 6.0 & 5.5 & 0.6 & 11.5 & 30.1 & 0.2 \\
\hline Forestry policy and administrative management & 6.0 & 19.1 & 37.6 & 49.9 & 11.3 & 38.0 & 3.8 & 58.7 & 4.2 & 42.8 & 271.4 & 1.8 \\
\hline
\end{tabular}




\begin{tabular}{|c|c|c|c|c|c|c|c|c|c|c|c|c|}
\hline Area & 2008 & 2009 & 2010 & 2011 & 2012 & 2013 & 2014 & 2015 & 2016 & 2017 & Total & Share, \% \\
\hline Forestry research & 0.0 & 0.1 & 0.4 & 0.3 & 0.0 & 0.0 & 0.0 & 0.1 & 0.0 & 0.0 & 1.0 & 0.0 \\
\hline Forestry service & 0.0 & 0.0 & 0.0 & 0.2 & 0.0 & 7.0 & 0.0 & 0.0 & 0.0 & 0.0 & 7.2 & 0.0 \\
\hline Fuelwood or charcoal & 0.0 & 0.0 & 0.0 & 0.0 & 6.5 & 0.0 & 0.0 & 0.0 & 0.0 & 0.0 & 6.5 & 0.0 \\
\hline Site preservation & 9.3 & 4.0 & 4.4 & 1.3 & 21.0 & 0.6 & 1.6 & 26.6 & 2.8 & 10.0 & 81.6 & 0.5 \\
\hline Sub-Total & 188.7 & 353.6 & 619.7 & 452.0 & 522.7 & 426.5 & 436.6 & 852.7 & 656.3 & 552.8 & 5061.7 & 34.1 \\
\hline \multicolumn{13}{|l|}{ Southeast Asia } \\
\hline Biodiversity & 19.5 & 8.3 & 85.9 & 82.3 & 131.0 & 56.3 & 121.7 & 67.7 & 68.5 & 71.9 & 713.1 & 4.8 \\
\hline Biosphere protection & 9.1 & 9.7 & 10.1 & 18.6 & 94.7 & 72.5 & 59.8 & 66.1 & 130.0 & 46.7 & 517.4 & 3.5 \\
\hline Environmental education or training & 2.0 & 4.9 & 3.4 & 4.6 & 3.1 & 3.0 & 5.3 & 2.1 & 0.8 & 0.7 & 29.9 & 0.2 \\
\hline $\begin{array}{l}\text { Environmental policy and administrative } \\
\text { management }\end{array}$ & 586.8 & 726.2 & 849.6 & 321.1 & 263.0 & 393.3 & 321.8 & 314.0 & 338.3 & 181.9 & 4296.0 & 29.0 \\
\hline Environmental research & 2.1 & 2.2 & 19.5 & 15.8 & 12.1 & 2.8 & 2.9 & 6.3 & 9.3 & 79.5 & 152.6 & 1.0 \\
\hline Flood prevention or control & 1.2 & 72.5 & 69.2 & 95.8 & 222.2 & 50.2 & 21.0 & 126.3 & 282.2 & 386.3 & 1326.8 & 8.9 \\
\hline Forest education or training & 34.1 & 27.1 & 7.3 & 17.9 & 37.6 & 11.5 & 24.8 & 2.6 & 1.2 & 15.4 & 179.5 & 1.2 \\
\hline Forestry development & 8.6 & 2.5 & 1.8 & 2.5 & 27.8 & 4.0 & 3.2 & 0.4 & 18.1 & 86.6 & 155.4 & 1.0 \\
\hline Forestry policy and administrative management & 32.8 & 11.9 & 45.3 & 47.2 & 211.8 & 77.8 & 79.3 & 28.2 & 105.9 & 18.2 & 658.5 & 4.4 \\
\hline Forestry research & 0.5 & 0.7 & 1.1 & 3.3 & 0.4 & 0.3 & 2.6 & 0.9 & 1.2 & 0.3 & 11.3 & 0.1 \\
\hline Forestry service & 0.2 & 0.2 & 0.1 & 5.3 & 0.1 & 7.0 & 0.0 & 0.0 & 0.0 & 0.0 & 13.0 & 0.1 \\
\hline Fuelwood or charcoal & 0.0 & 0.0 & 0.0 & 0.0 & 0.0 & 0.0 & 0.0 & 0.0 & 0.0 & 0.0 & 0.0 & 0.0 \\
\hline Site preservation & 5.0 & 1.6 & 0.7 & 2.3 & 1.3 & 4.1 & 2.4 & 4.8 & 1.2 & 2.6 & 25.9 & 0.2 \\
\hline Sub-Total & 701.9 & 867.8 & 1094.0 & 616.9 & 1005.3 & 682.8 & 644.8 & 619.3 & 956.7 & 890.2 & 8079.6 & 54.5 \\
\hline Grand Total & 1041.6 & 1354.6 & 1815.6 & 1218.6 & 1664.1 & 1371.8 & 1187.8 & 1786.4 & 1852.8 & 1543.9 & 14837.3 & 100 \\
\hline
\end{tabular}




\section{Appendix 8. Bilateral FEODA by area and by tropical zone (USD million)}

\begin{tabular}{|c|c|c|c|c|c|c|c|c|c|c|c|c|}
\hline Area & 2008 & 2009 & 2010 & 2011 & 2012 & 2013 & 2014 & 2015 & 2016 & 2017 & Total & Share, \% \\
\hline \multicolumn{13}{|l|}{ CA } \\
\hline Biodiversity & 21.2 & 11.9 & 9.7 & 38.8 & 53.8 & 63.4 & 12.1 & 27.8 & 45.0 & 5.3 & 288.9 & 2.5 \\
\hline Biosphere protection & 0.8 & 0.3 & 0.4 & 1.4 & 7.7 & 1.4 & 2.7 & 5.1 & 1.8 & 4.4 & 26.0 & 0.2 \\
\hline Environmental education or training & 0.3 & 0.6 & 0.3 & 0.2 & 0.4 & 0.7 & 0.5 & 0.1 & 0.3 & 0.2 & 3.5 & 0.0 \\
\hline $\begin{array}{l}\text { Environmental policy and administrative } \\
\text { management }\end{array}$ & 29.9 & 23.9 & 20.8 & 9.8 & 4.6 & 11.5 & 25.2 & 21.4 & 39.3 & 6.6 & 193.0 & 1.7 \\
\hline Environmental research & 0.9 & 5.0 & 2.1 & 5.6 & 4.9 & 82.2 & 3.4 & 62.3 & 13.4 & 5.1 & 184.9 & 1.6 \\
\hline Flood prevention or control & 0.0 & 0.0 & 2.8 & 0.0 & 0.0 & 0.0 & 0.0 & 0.0 & 11.3 & 0.0 & 14.1 & 0.1 \\
\hline Forest education or training & 0.5 & 2.4 & 0.4 & 0.3 & 0.6 & 0.6 & 0.0 & 2.0 & 3.3 & 34.1 & 44.2 & 0.4 \\
\hline Forestry development & 3.9 & 0.1 & 0.1 & 0.2 & 0.1 & 0.2 & 0.1 & 0.2 & 0.0 & 0.0 & 5.0 & 0.0 \\
\hline $\begin{array}{l}\text { Forestry policy and administrative } \\
\text { management }\end{array}$ & 9.0 & 8.5 & 35.5 & 6.8 & 8.5 & 4.2 & 8.5 & 9.0 & 11.9 & 3.4 & 105.3 & 0.9 \\
\hline Forestry research & 0.0 & 0.0 & 0.0 & 0.2 & 0.2 & 0.1 & 0.5 & 0.3 & 0.0 & 0.0 & 1.4 & 0.0 \\
\hline Forestry service & 0.0 & 0.0 & 0.0 & 3.8 & 0.0 & 0.0 & 0.0 & 0.0 & 0.0 & 0.0 & 3.8 & 0.0 \\
\hline Fuelwood or charcoal & 0.0 & 0.0 & 0.0 & 0.0 & 0.0 & 7.1 & 0.0 & 1.7 & 0.0 & 0.1 & 8.9 & 0.1 \\
\hline Site preservation & 0.3 & 2.5 & 5.3 & 0.0 & 0.1 & 0.1 & 0.1 & 0.8 & 1.5 & 0.0 & 10.7 & 0.1 \\
\hline Sub-Total & 66.8 & 55.2 & 77.5 & 67.1 & 81.0 & 171.5 & 53.0 & 130.5 & 128.0 & 59.2 & 889.8 & 7.6 \\
\hline \multicolumn{13}{|l|}{ Amazon Basin } \\
\hline Biodiversity & 49.1 & 85.7 & 68.5 & 132.1 & 75.8 & 76.1 & 87.9 & 175.6 & 46.2 & 194.4 & 991.4 & 8.5 \\
\hline Biosphere protection & 3.3 & 5.4 & 20.5 & 22.1 & 33.7 & 32.9 & 31.3 & 19.7 & 9.6 & 17.7 & 196.3 & 1.7 \\
\hline Environmental education or training & 1.8 & 3.0 & 1.6 & 1.3 & 1.3 & 3.3 & 2.0 & 3.1 & 0.6 & 2.8 & 20.7 & 0.2 \\
\hline $\begin{array}{l}\text { Environmental policy and administrative } \\
\text { management }\end{array}$ & 57.5 & 131.3 & 422.7 & 183.4 & 252.2 & 207.0 & 243.4 & 492.3 & 388.3 & 173.1 & 2551.3 & 21.8 \\
\hline Environmental research & 2.6 & 4.2 & 8.0 & 11.8 & 10.6 & 4.4 & 1.7 & 7.8 & 18.0 & 18.6 & 87.6 & 0.7 \\
\hline Flood prevention or control & 19.9 & 0.2 & 5.4 & 9.3 & 0.3 & 0.0 & 23.4 & 0.0 & 0.2 & 0.1 & 58.9 & 0.5 \\
\hline Forest education or training & 1.4 & 26.1 & 6.5 & 3.1 & 1.2 & 1.0 & 0.4 & 3.3 & 42.0 & 11.8 & 96.7 & 0.8 \\
\hline Forestry development & 0.0 & 0.5 & 0.1 & 0.4 & 0.2 & 0.0 & 0.0 & 0.0 & 0.0 & 0.0 & 1.4 & 0.0 \\
\hline
\end{tabular}




\begin{tabular}{|c|c|c|c|c|c|c|c|c|c|c|c|c|}
\hline Area & 2008 & 2009 & 2010 & 2011 & 2012 & 2013 & 2014 & 2015 & 2016 & 2017 & Total & Share, \% \\
\hline $\begin{array}{l}\text { Forestry policy and administrative } \\
\text { management }\end{array}$ & 5.9 & 13.3 & 35.9 & 49.3 & 2.8 & 1.9 & 1.9 & 48.3 & 4.0 & 4.2 & 167.5 & 1.4 \\
\hline Forestry research & 0.0 & 0.1 & 0.4 & 0.3 & 0.0 & 0.0 & 0.0 & 0.1 & 0.0 & 0.0 & 1.0 & 0.0 \\
\hline Forestry service & 0.0 & 0.0 & 0.0 & 0.2 & 0.0 & 7.0 & 0.0 & 0.0 & 0.0 & 0.0 & 7.2 & 0.1 \\
\hline Fuelwood or charcoal & 0.0 & 0.0 & 0.0 & 0.0 & 0.0 & 0.0 & 0.0 & 0.0 & 0.0 & 0.0 & 0.0 & 0.0 \\
\hline Site preservation & 9.3 & 4.0 & 4.4 & 1.3 & 9.4 & 0.6 & 1.6 & 26.6 & 2.8 & 10.0 & 70.0 & 0.6 \\
\hline Sub-Total & 150.9 & 273.7 & 574.2 & 414.7 & 387.6 & 334.3 & 393.6 & 776.8 & 511.7 & 432.6 & 4249.9 & 36.3 \\
\hline \multicolumn{13}{|l|}{ Southeast Asia } \\
\hline Biodiversity & 19.1 & 8.1 & 71.7 & 81.5 & 61.2 & 34.2 & 89.7 & 51.7 & 50.1 & 48.5 & 516.0 & 4.4 \\
\hline Biosphere protection & 9.1 & 9.7 & 10.1 & 11.5 & 87.4 & 65.7 & 58.6 & 66.1 & 59.0 & 46.7 & 424.0 & 3.6 \\
\hline Environmental education or training & 2.0 & 4.9 & 3.1 & 4.6 & 3.1 & 2.3 & 5.3 & 2.1 & 0.8 & 0.7 & 29.0 & 0.2 \\
\hline $\begin{array}{l}\text { Environmental policy and administrative } \\
\text { management }\end{array}$ & 560.6 & 641.1 & 832.7 & 272.6 & 180.5 & 367.1 & 279.1 & 278.5 & 214.9 & 162.0 & 3789.1 & 32.4 \\
\hline Environmental research & 2.1 & 2.2 & 19.5 & 15.8 & 12.1 & 2.8 & 2.9 & 6.3 & 9.3 & 11.5 & 84.6 & 0.7 \\
\hline Flood prevention or control & 1.1 & 72.5 & 68.9 & 64.6 & 222.2 & 35.6 & 7.5 & 126.3 & 220.4 & 188.4 & 1007.4 & 8.6 \\
\hline Forest education or training & 34.1 & 27.1 & 7.3 & 17.9 & 37.6 & 11.5 & 24.8 & 2.6 & 1.2 & 15.4 & 179.5 & 1.5 \\
\hline Forestry development & 0.4 & 0.5 & 0.7 & 0.3 & 0.1 & 0.1 & 2.4 & 0.0 & 0.0 & 0.0 & 4.4 & 0.0 \\
\hline $\begin{array}{l}\text { Forestry policy and administrative } \\
\text { management }\end{array}$ & 19.8 & 11.4 & 38.2 & 46.5 & 196.0 & 35.8 & 68.4 & 10.8 & 32.5 & 16.2 & 475.5 & 4.1 \\
\hline Forestry research & 0.5 & 0.7 & 1.1 & 3.3 & 0.4 & 0.3 & 2.6 & 0.9 & 1.2 & 0.3 & 11.3 & 0.1 \\
\hline Forestry service & 0.2 & 0.2 & 0.1 & 5.3 & 0.1 & 7.0 & 0.0 & 0.0 & 0.0 & 0.0 & 13.0 & 0.1 \\
\hline Fuelwood or charcoal & 0.0 & 0.0 & 0.0 & 0.0 & 0.0 & 0.0 & 0.0 & 0.0 & 0.0 & 0.0 & 0.0 & 0.0 \\
\hline Site preservation & 5.0 & 1.6 & 0.4 & 2.3 & 0.9 & 4.1 & 2.4 & 4.8 & 1.2 & 2.6 & 25.3 & 0.2 \\
\hline Sub-Total & 654.0 & 779.9 & 1053.9 & 526.3 & 801.7 & 566.4 & 543.8 & 550.1 & 590.7 & 492.3 & 6559.0 & 56.1 \\
\hline Grand Total & 871.7 & 1108.8 & 1705.5 & 1008.1 & 1270.2 & 1072.2 & 990.4 & 1457.5 & 1230.3 & 984.0 & 11698.7 & 100 \\
\hline
\end{tabular}


Appendix 9. Multilateral FEODA by area and by tropical zone (USD million)

\begin{tabular}{|c|c|c|c|c|c|c|c|c|c|c|c|c|}
\hline Area & 2008 & 2009 & 2010 & 2011 & 2012 & 2013 & 2014 & 2015 & 2016 & 2017 & Total & Share, \% \\
\hline \multicolumn{13}{|l|}{ CA } \\
\hline Biodiversity & 36.0 & 4.8 & 2.7 & 22.9 & 10.9 & 15.7 & 7.7 & 0.1 & 45.5 & 13.7 & 160.1 & 5.1 \\
\hline Biosphere protection & 0.0 & 0.0 & 0.9 & 8.2 & 2.8 & 4.3 & 0.0 & 134.1 & 0.0 & 0.0 & 150.4 & 4.8 \\
\hline Environmental education or training & 0.0 & 0.0 & 0.0 & 0.0 & 0.0 & 0.0 & 0.0 & 0.0 & 0.0 & 0.0 & 0.0 & 0.0 \\
\hline $\begin{array}{l}\text { Environmental policy and } \\
\text { administrative management }\end{array}$ & 39.0 & 28.7 & 2.9 & 26.0 & 17.5 & 43.0 & 11.5 & 31.9 & 42.8 & 10.0 & 253.3 & 8.1 \\
\hline Environmental research & 0.0 & 0.0 & 0.0 & 0.0 & 0.0 & 0.0 & 0.0 & 0.0 & 0.0 & 0.0 & 0.0 & 0.0 \\
\hline Flood prevention or control & 0.0 & 0.0 & 11.2 & 1.1 & 0.0 & 2.9 & 0.0 & 11.2 & 6.7 & 0.0 & 33.0 & 1.1 \\
\hline Forest education or training & 0.0 & 0.0 & 0.0 & 0.0 & 0.0 & 0.0 & 0.0 & 0.0 & 0.0 & 0.0 & 0.0 & 0.0 \\
\hline Forestry development & 5.4 & 21.8 & 2.1 & 0.1 & 1.4 & 0.1 & 0.0 & 6.2 & 5.8 & 7.5 & 50.4 & 1.6 \\
\hline $\begin{array}{l}\text { Forestry policy and administrative } \\
\text { management }\end{array}$ & 3.8 & 18.3 & 4.4 & 24.2 & 13.4 & 24.5 & 33.8 & 0.0 & 11.1 & 10.4 & 144.1 & 4.6 \\
\hline Forestry research & 0.0 & 0.0 & 0.0 & 0.0 & 0.0 & 0.0 & 0.0 & 0.0 & 0.0 & 0.0 & 0.0 & 0.0 \\
\hline Forestry service & 0.0 & 0.0 & 0.0 & 0.0 & 0.0 & 0.0 & 0.2 & 0.0 & 0.0 & 0.0 & 0.2 & 0.0 \\
\hline Fuelwood or charcoal & 0.0 & 0.0 & 0.0 & 0.0 & 0.0 & 0.0 & 0.0 & 0.0 & 0.0 & 0.0 & 0.0 & 0.0 \\
\hline Site preservation & 0.0 & 4.5 & 0.1 & 0.1 & 9.0 & 0.4 & 0.2 & 0.4 & 0.0 & 0.0 & 14.6 & 0.5 \\
\hline Sub-Total & 84.2 & 78.1 & 24.4 & 82.6 & 55.2 & 91.0 & 53.4 & 183.9 & 111.8 & 41.7 & 806.2 & 25.7 \\
\hline \multicolumn{13}{|l|}{ Amazon Basin } \\
\hline Biodiversity & 0.0 & 5.7 & 29.2 & 18.5 & 84.2 & 20.9 & 17.0 & 29.4 & 50.9 & 67.1 & 322.9 & 10.3 \\
\hline Biosphere protection & 0.0 & 0.0 & 6.9 & 3.1 & 2.1 & 2.3 & 6.5 & 2.3 & 0.0 & 0.0 & 23.2 & 0.7 \\
\hline Environmental education or training & 0.0 & 0.0 & 0.0 & 0.0 & 0.0 & 0.0 & 0.0 & 0.0 & 0.0 & 0.3 & 0.3 & 0.0 \\
\hline $\begin{array}{l}\text { Environmental policy and } \\
\text { administrative management }\end{array}$ & 36.9 & 61.8 & 7.0 & 14.0 & 21.2 & 15.3 & 1.0 & 28.3 & 59.8 & 2.8 & 248.1 & 7.9 \\
\hline Environmental research & 0.0 & 0.0 & 0.0 & 0.0 & 0.0 & 0.0 & 0.0 & 0.0 & 0.0 & 0.0 & 0.0 & 0.0 \\
\hline Flood prevention or control & 0.0 & 5.0 & 0.0 & 0.0 & 0.8 & 16.9 & 10.7 & 0.0 & 33.2 & 0.0 & 66.5 & 2.1 \\
\hline Forest education or training & 0.0 & 0.0 & 0.0 & 0.0 & 0.0 & 0.0 & 0.0 & 0.0 & 0.0 & 0.0 & 0.0 & 0.0 \\
\hline
\end{tabular}




\begin{tabular}{|c|c|c|c|c|c|c|c|c|c|c|c|c|}
\hline Area & 2008 & 2009 & 2010 & 2011 & 2012 & 2013 & 2014 & 2015 & 2016 & 2017 & Total & Share, $\%$ \\
\hline Forestry development & 0.8 & 1.5 & 0.7 & 1.2 & 0.1 & 0.8 & 6.0 & 5.5 & 0.6 & 11.5 & 28.7 & 0.9 \\
\hline $\begin{array}{l}\text { Forestry policy and administrative } \\
\text { management }\end{array}$ & 0.1 & 5.8 & 1.7 & 0.6 & 8.5 & 36.0 & 1.9 & 10.4 & 0.2 & 38.6 & 104.0 & 3.3 \\
\hline Forestry research & 0.0 & 0.0 & 0.0 & 0.0 & 0.0 & 0.0 & 0.0 & 0.0 & 0.0 & 0.0 & 0.0 & 0.0 \\
\hline Forestry service & 0.0 & 0.0 & 0.0 & 0.0 & 0.0 & 0.0 & 0.0 & 0.0 & 0.0 & 0.0 & 0.0 & 0.0 \\
\hline Fuelwood or charcoal & 0.0 & 0.0 & 0.0 & 0.0 & 6.5 & 0.0 & 0.0 & 0.0 & 0.0 & 0.0 & 6.5 & 0.2 \\
\hline Site preservation & 0.0 & 0.0 & 0.0 & 0.0 & 11.6 & 0.0 & 0.0 & 0.0 & 0.0 & 0.0 & 11.6 & 0.4 \\
\hline Sub-Total & 37.8 & 79.9 & 45.5 & 37.3 & 135.1 & 92.2 & 43.1 & 75.9 & 144.7 & 120.3 & 811.8 & 25.9 \\
\hline \multicolumn{13}{|l|}{ Southeast Asia } \\
\hline Biodiversity & 0.4 & 0.2 & 14.2 & 0.8 & 69.8 & 22.1 & 31.9 & 15.9 & 18.4 & 23.4 & 197.2 & 6.3 \\
\hline Biosphere protection & 0.0 & 0.0 & 0.0 & 7.1 & 7.4 & 6.8 & 1.1 & 0.0 & 71.0 & 0.0 & 93.5 & 3.0 \\
\hline Environmental education or training & 0.0 & 0.0 & 0.3 & 0.0 & 0.0 & 0.7 & 0.0 & 0.0 & 0.0 & 0.0 & 1.0 & 0.0 \\
\hline $\begin{array}{l}\text { Environmental policy and } \\
\text { administrative management }\end{array}$ & 26.2 & 85.0 & 17.0 & 48.5 & 82.5 & 26.2 & 42.7 & 35.5 & 123.4 & 20.0 & 506.9 & 16.2 \\
\hline Environmental research & 0.0 & 0.0 & 0.0 & 0.0 & 0.0 & 0.0 & 0.0 & 0.0 & 0.0 & 68.0 & 68.0 & 2.2 \\
\hline Flood prevention or control & 0.1 & 0.1 & 0.3 & 31.2 & 0.0 & 14.6 & 13.5 & 0.0 & 61.8 & 197.9 & 319.4 & 10.2 \\
\hline Forest education or training & 0.0 & 0.0 & 0.0 & 0.0 & 0.0 & 0.0 & 0.0 & 0.0 & 0.0 & 0.0 & 0.0 & 0.0 \\
\hline Forestry development & 8.3 & 2.1 & 1.0 & 2.2 & 27.7 & 3.9 & 0.8 & 0.3 & 18.1 & 86.6 & 151.0 & 4.8 \\
\hline $\begin{array}{l}\text { Forestry policy and administrative } \\
\text { management }\end{array}$ & 13.0 & 0.5 & 7.0 & 0.7 & 15.9 & 42.0 & 10.9 & 17.4 & 73.4 & 2.0 & 183.0 & 5.8 \\
\hline Forestry research & 0.0 & 0.0 & 0.0 & 0.0 & 0.0 & 0.0 & 0.0 & 0.0 & 0.0 & 0.0 & 0.0 & 0.0 \\
\hline Forestry service & 0.0 & 0.0 & 0.0 & 0.0 & 0.0 & 0.0 & 0.0 & 0.0 & 0.0 & 0.0 & 0.0 & 0.0 \\
\hline Fuelwood or charcoal & 0.0 & 0.0 & 0.0 & 0.0 & 0.0 & 0.0 & 0.0 & 0.0 & 0.0 & 0.0 & 0.0 & 0.0 \\
\hline Site preservation & 0.0 & 0.0 & 0.3 & 0.0 & 0.3 & 0.0 & 0.0 & 0.0 & 0.0 & 0.0 & 0.6 & 0.0 \\
\hline Sub-Total & 47.9 & 87.9 & 40.1 & 90.5 & 203.6 & 116.4 & 101.0 & 69.2 & 366.1 & 397.9 & 1520.5 & 48.4 \\
\hline Grand Total & 170.0 & 245.8 & 110.1 & 210.4 & 393.9 & 299.6 & 197.4 & 329.0 & 622.5 & 559.8 & 3138.6 & 100 \\
\hline
\end{tabular}



Central Africa is home to the second largest rainforest in the world, the Congo Basin. However, while this massive forest block stores huge amounts of carbon, it receives significantly less international funding than the Amazon and Southeast Asia's forests. Financing being a central to combat climate change, this study aims to map international flows supporting the forest and environment sectors in Central Africa.

This publication analyses the funding flows over the last decade in support of nature conservation and sustainable management of the Congo Basin, presents various themes covered by the current financing and identifies possible imbalances. It also provides a comparative analysis between financing flows to the various forest basins in the world and identifies opportunities for increasing financing for forests in Central Africa.

Specifically, the report provides data on the Official Development Assistance (ODA) to Central Africa in the period 2008-2017. The authors, using a well-structured methodology bring out the various characteristics of funding to Central African countries highlighting the top bilateral donor, Germany, and the top multilateral donor, the European Union.

Richard Eba'a Atyi, lead author, is the regional coordinator for the Center of International Forestry Research (CIFOR) in Central Africa. He also coordinates the Strengthening and institutionalization of the Central African Forest Observatory (RIOFAC) project which supported this study. He worked in collaboration with Liboum Mbonayem - forestry engineer and research officer at CIFOR in Central Africa, Phillipe Guizol - senior scientist at CIFOR and The French Agricultural Research Centre for International Development (CIRAD) and Ibrahim M. Favada - Forest economist. 